\title{
Matrix isolation and low temperature solid state FTIR spectroscopic study of $\alpha$-furil $\dagger$
}

\author{
Susy Lopes, ${ }^{a}$ Andrea Gómez-Zavaglia ${ }^{a b}$ and Rui Fausto ${ }^{* a}$ \\ Received 14th November 2005, Accepted 24th January 2006 \\ First published as an Advance Article on the web 7th March 2006 \\ DOI: $10.1039 / \mathbf{b 5 1 6 1 6 4 a}$
}

$\alpha$-Furil $\left[\mathrm{C}_{4} \mathrm{H}_{3} \mathrm{O}-\mathrm{C}(=\mathrm{O})-\mathrm{C}(=\mathrm{O})-\mathrm{C}_{4} \mathrm{H}_{3} \mathrm{O}\right]$ has been isolated in argon and xenon matrices and studied by FTIR spectroscopy, supported by DFT(B3LYP)/6-311++G(d,p) calculations. The obtained spectra were fully assigned and revealed the presence in the matrices of three different conformers, all of them exhibiting skewed conformations around the intercarbonyl bond with the two $\mathrm{C}_{4} \mathrm{H}_{3} \mathrm{O}-\mathrm{C}(=\mathrm{O})$ fragments nearly planar. The three conformers differ in the orientation of the furan rings relative to the carbonyl groups: the most stable conformer, I $\left(C_{2}\right.$ symmetry; $\mathrm{O}=\mathrm{C}-\mathrm{C}=\mathrm{O}$ intercarbonyl dihedral equal to $153.1^{\circ}$ ), has both furan rings orientated in such a way that one of their $\beta$-hydrogen atoms approaches the oxygen atom of the most distant carbonyl group, forming two $\mathrm{H}-\mathrm{C}=\mathrm{C}-\mathrm{C}-\mathrm{C}=\mathrm{O}$ six-membered rings; the second most stable conformer, II $\left(C_{1}\right.$ symmetry; $\mathrm{O}=\mathrm{C}-\mathrm{C}=\mathrm{O}$ intercarbonyl dihedral equal to $\left.126.9^{\circ}\right)$, has one furan ring orientated as in $\mathbf{I}$, while the second furan group is rotated by $c a .180^{\circ}$ (resulting in an energetically less favourable $\mathrm{H}-\mathrm{C}=\mathrm{C}-\mathrm{C}=\mathrm{O}$ five-membered ring); in the third conformer, III $\left(C_{2}\right.$ symmetry; $\mathrm{O}=\mathrm{C}-\mathrm{C}=\mathrm{O}$ dihedral equal to $106.2^{\circ}$ ), both furan rings assume the latter orientation relative to the dicarbonyl group. The theoretical calculations predicted the two higher energy forms being 5.85 and $6.22 \mathrm{~kJ} \mathrm{~mol}^{-1}$ higher in energy than the most stable form, respectively, and energy barriers for conformational interconversion higher than $40 \mathrm{~kJ} \mathrm{~mol}^{-1}$. These barriers are high enough to prevent observation of conformational isomerization for the matrix isolated compound. The three possible conformers of $\alpha$-furil were also found to be present in $\mathrm{CCl}_{4}$ solution, as well as in a low temperature neat amorphous phase of the compound prepared from fast condensation of its vapour onto a suitable $10 \mathrm{~K}$ cooled substrate. On the other hand, in agreement with the available X-ray data [S. C. Biswas, S. Ray and A. Podder, Chem. Phys. Lett., 1987, 134, 541], the IR spectra obtained for the neat low temperature crystalline state reveals that, in this phase, $\alpha$-furil exists uniquely in its most stable conformational state, $\mathbf{I}$.

\section{Introduction}

Simple $\alpha$-dicarbonyl compounds have received much attention due to the photorotamerism they frequently exhibit. ${ }^{1-6}$ These compounds have been found to be considerably flexible, and the large amplitude, low frequency vibrational mode associated with the $\mathrm{O}=\mathrm{C}-\mathrm{C}=\mathrm{O}$ intercarbonyl torsional coordinate has been shown to significantly influence their physicochemical properties. $^{7-12}$ In several $\alpha$-dicarbonyl compounds, a long wavelength $n-\pi^{*}$ transition occurs at $\lambda_{\max }$ in the range $c a .440-500 \mathrm{~nm}$ for both cis- and trans-coplanar dicarbonyl arrangements, shifting to substantially higher energies $\left(\lambda_{\max }<c a .440 \mathrm{~nm}\right)$ whenever the intercarbonyl dihedral angle deviates significantly from planarity. ${ }^{13-17}$ Benzil $\left[\mathrm{C}_{6} \mathrm{H}_{5}-\mathrm{C}(=\mathrm{O})-\mathrm{C}(=\mathrm{O})-\mathrm{C}_{6} \mathrm{H}_{5}\right], \alpha$-pyridil $\left[\mathrm{C}_{6} \mathrm{NH}_{4}-\mathrm{C}(=\mathrm{O})-\mathrm{C}\right.$ $\left.(=\mathrm{O})-\mathrm{C}_{6} \mathrm{NH}_{4}\right]$ and 1-phenyl-1,2-propanedione $\left[\mathrm{C}_{6} \mathrm{H}_{5}-\mathrm{C}(=\mathrm{O})\right.$

\footnotetext{
${ }^{a}$ Department of Chemistry, University of Coimbra, $P$-3004-535

Coimbra,Portugal.E-mail: rfausto@ci.uc.pt

${ }^{b}$ Faculdad de Farmacia y Bioquimica, Universidad de Buenos Aires, Junín 956, Buenos Aires 1113, Argentina

$\dagger$ Electronic supplementary information (ESI) available: Tables S1-S5, with definition of symmetry coordinates, calculated frequencies and intensities, and results of normal coordinate analysis. See DOI: $10.1039 / \mathrm{b} 516164 \mathrm{a}$
}

$\left.-\mathrm{C}(=\mathrm{O})-\mathrm{CH}_{3}\right]$ are examples of simple $\alpha$-dicarbonyl compounds showing this characteristic behaviour. ${ }^{5,6,8-18}$ In $\alpha$-furil, the maximum of the $n-\pi^{*}$ band position was found to occur at about $425 \mathrm{~nm}$ (in cyclohexane solution), compared with 355 and $385 \mathrm{~nm}$ for benzil and $\alpha$-pyridil, respectively. ${ }^{18}$ According to the expected correlation between the maximum absorption frequency and the $\mathrm{O}=\mathrm{C}-\mathrm{C}=\mathrm{O}$ intercarbonyl dihedral angle, ${ }^{17-19}$ this observation indicates that $\alpha$-furil exists preferentially in a conformation exhibiting a more transoid-like dicarbonyl moiety than both benzil and $\alpha$-pyridil, which have intercarbonyl dihedral angles of $c a .100$ and $120^{\circ}$, respectively. ${ }^{8,11,18,20}$ However, $\alpha$-furil has not yet been the subject of any detailed structural study, with the exception of the Xray diffraction investigation of Biswas, Ray and Podder. ${ }^{21}$ Very interestingly, in the crystal the intercarbonyl dihedral angle in $\alpha$-furil was found to be $131^{\circ}$, which is in agreement with the expected value based on the aforementioned correlation, although in this phase the preferred conformation is expected to have a smaller intercarbonyl dihedral angle than the isolated molecule. Indeed, more polar structures are expected to be stabilized in the crystalline phase when compared to the isolated molecule (or for the compound in an apolar solvent like cyclohexane) and, in $\alpha$-furil, the dipole 
moment grows from zero in the planar trans-structure to a maximum value (over $5 \mathrm{D}$ ) in the planar cis-conformation. In any case, a detailed analysis of the preferred conformations of $\alpha$-furil had not been reported hitherto. Moreover, the need for such study is also strongly reinforced by the fact that $\alpha$-furil finds applications in both electronic display devices and photoimaging, for which precise knowledge of the structural details of the compound is of great importance. ${ }^{22-24}$

In the present study, the conformational space of $\alpha$-furil was investigated by a concerted approach based on matrix-isolation and low temperature solid-state infrared spectroscopy and DFT(B3LYP)/6-311+ + G(d,p) theoretical calculations. Temperature variation studies of the infrared spectrum of $\alpha$-furil in a $\mathrm{CCl}_{4}$ diluted solution were also undertaken over the temperature range $300-350 \mathrm{~K}$. As will be described in the following sections, these studies enabled the identification of three different conformers of $\alpha$-furil in the gas phase as well as in solution, a low temperature amorphous phase resulting from fast deposition of the gaseous compound onto a $10 \mathrm{~K}$ cooled substrate, and both argon and xenon matrices. The most stable form observed for all investigated conditions was found to correspond to the conformer that was previously reported in the crystalline phase. ${ }^{21}$

\section{Materials and methods}

\section{Infrared spectroscopy}

$\alpha$-Furil (98\% purity) was obtained from Aldrich, and used without any further purification.

The IR spectra were recorded with $0.5 \mathrm{~cm}^{-1}$ spectral resolution in a Mattson (Infinity 60AR Series) Fourier Transform infrared spectrometer, equipped with a deuterated triglycine sulphate (DTGS) detector and a $\mathrm{Ge} / \mathrm{KBr}$ beam splitter. It was necessary to modify the sample compartment of the spectrometer in order to accommodate the cryostat head and allow purging of the instrument by a stream of gaseous $\mathrm{N}_{2}$, to remove water vapour and $\mathrm{CO}_{2}$. The solid sample of $\alpha$-furil was placed in a specially designed doubly thermostatted Knudsen cell. $^{25}$ Matrices were prepared by co-deposition of $\alpha$-furil vapours coming out of the Knudsen cell and a large excess of the matrix gas (argon, N60; xenon, N48, both obtained from Air Liquide) onto the CsI substrate of the cryostat (APD Cryogenics, model DE-202A), which was cooled to selected temperatures ranging from 10-25 K. Different nozzle temperatures were used during preparation of the matrices, varying from 393 to $413 \mathrm{~K}$. After depositing the compound, annealing of the matrices was performed up to 40 or $80 \mathrm{~K}$ for argon and xenon matrices, respectively.

The low temperature solid amorphous layer was prepared in the same way as matrices but with the flux of matrix gas cut off. The layer was then allowed to anneal at a slowly increasing temperature up to $260 \mathrm{~K}$. After the temperature exceeded $170 \mathrm{~K}$, crystallization of the amorphous layer occurred. Subsequently, the CsI substrate was cooled back to $10 \mathrm{~K}$ and the spectrum of the crystalline phase was recorded.

Temperature variation solution studies were carried out for the compound in a $\mathrm{CCl}_{4}$ diluted solution $\left(<10^{-3} \mathrm{M}\right)$, using a Specac temperature variation cell in a BOMEM (MB40) spectrometer, which has a $\mathrm{Zn} / \mathrm{Se}$ beam splitter and a DTGS detector, with $4 \mathrm{~cm}^{-1}$ resolution.

\section{Computational methodology}

The quantum chemical calculations were performed with Gaussian 98 (Revision A.9) $^{26}$ at the DFT level of theory, using the split valence triple- $\zeta 6-311++\mathrm{G}(\mathrm{d}, \mathrm{p})$ basis set and the three-parameter B3LYP density functional, which includes Becke's gradient exchange correction ${ }^{27}$ and the Lee, Yang and Parr correlation functional. ${ }^{28}$

Geometrical parameters of the considered conformations were optimized using the Geometry Direct Inversion of the Invariant Subspace (GDIIS) method. ${ }^{29}$ In order to assist the analysis of the experimental spectra, vibrational frequencies and IR intensities were also calculated at the same level of approximation. The computed harmonic frequencies were scaled down by a single factor (0.978) to correct them for the effects of basis set limitations, the neglected part of electron correlation and anharmonicity effects. Calculations on the conformational transition states were also carried out at the same level of approximation. Normal coordinate analysis was undertaken in the internal coordinates space, as described by Schachtschneider, ${ }^{30}$ using an academic free program provided by Dr Leszek Lapinski (Institute of Physics, Polish Academy of Sciences, Warsaw, PL-02-668, Poland) and the optimized geometries and harmonic force constants resulting from the DFT(B3LYP)/6-311+ + G(d,p) calculations.

\section{Results and discussion}

\section{DFT(B3LYP)/6-311 + + G(d,p) calculations}

The DFT(B3LYP)/6-311 + $+\mathrm{G}(\mathrm{d}, \mathrm{p})$ calculations predicted the existence of three different conformers of $\alpha$-furil, which are displayed in Fig. 1. All three forms exhibit skewed conformations around the intercarbonyl bond with the two $\mathrm{C}_{4} \mathrm{H}_{3} \mathrm{O}-\mathrm{C}(=\mathrm{O})$ fragments nearly planar. The three conformers differ in the orientation of the furan rings relative to the carbonyl groups: the most stable conformer, $\mathrm{I}\left(C_{2}\right.$ symmetry; $\mathrm{O}=\mathrm{C}-\mathrm{C}=\mathrm{O}$ intercarbonyl dihedral equal to $\left.153.1^{\circ}\right)$, has both furan rings oriented in such a way that one of their $\beta$-hydrogen atoms approaches the oxygen atom of the most distant carbonyl group, forming two $\mathrm{H}-\mathrm{C}=\mathrm{C}-\mathrm{C}-\mathrm{C}=\mathrm{O}$ six-membered rings that are stabilized by a $\mathrm{CH} \cdots \mathrm{O}$ attractive interaction (the $\mathrm{CH} \cdots \mathrm{O}$ distance is considerably shorter than the sum of the $\mathrm{H}$ and $\mathrm{O}$ van der Waals radii; $243.5 \mathrm{pm}$ vs. $272 \mathrm{pm})$; the second most stable conformer, II $\left(C_{1}\right.$ symmetry; $\mathrm{O}=\mathrm{C}-\mathrm{C}=\mathrm{O}$ intercarbonyl dihedral equal to $126.9^{\circ}$ ) has one furan ring orientated as in $\mathbf{I}$, while the second furan group is rotated by $c a .180^{\circ}$, resulting in an energetically less favourable $\mathrm{H}-\mathrm{C}=\mathrm{C}-\mathrm{C}=\mathrm{O}$ five-membered ring (in this conformer, the calculated $\mathrm{CH}$. . O distances are 265.7 and 294.0 pm, for the six and five-membered rings, respectively); finally, in the third conformer, III $\left(C_{2}\right.$ symmetry; $\mathrm{O}=\mathrm{C}-\mathrm{C}=\mathrm{O}$ dihedral equal to $106.2^{\circ}$ ), both furan rings assume the latter orientation relative to the dicarbonyl group, the $\mathrm{CH}$... O distances in the two fivemembered rings being $299.0 \mathrm{pm}$. The theoretical calculations predict the less stable conformers II and III to be 5.85 and $6.22 \mathrm{~kJ} \mathrm{~mol}^{-1}$ higher in energy than the most stable form, respectively. 




$\Delta \mathrm{E}=0.00 \mathrm{~kJ} \mathrm{~mol}^{-1} ; \mu=2.05$ debye (153.1, $0.8,0.8$ degrees)

II

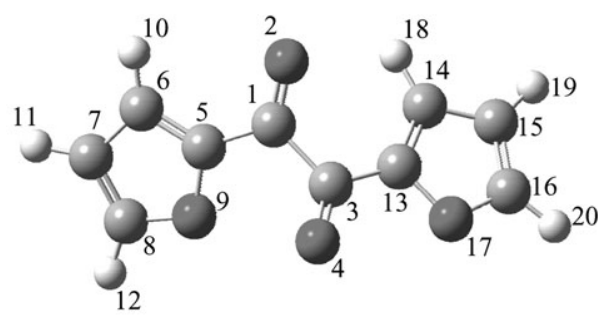

$\Delta \mathrm{E}=5.85 \mathrm{~kJ} \mathrm{~mol}^{-1} ; \mu=2.64$ debye $(126.9,172.5,3.3$ degrees $)$

\section{III}

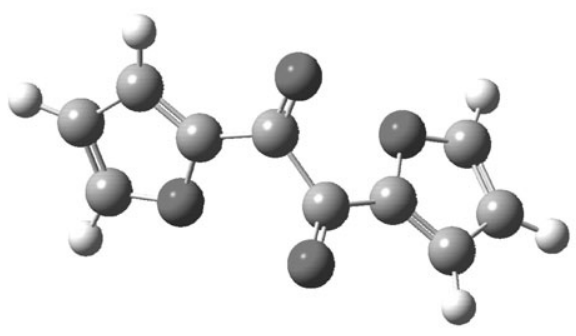

$\Delta \mathrm{E}=6.22 \mathrm{~kJ} \mathrm{~mol}^{-1} ; \mu=4.17$ debye

(106.2, 176.6, 176.6 degrees)

Fig. 1 Conformers of $\alpha$-furil, with atom numbering. Relative energies and dipole moments are also provided, as well as the $\mathrm{O}_{2}=\mathrm{C}_{1}-\mathrm{C}_{3}=\mathrm{O}_{4}$, $\mathrm{O}_{9}-\mathrm{C}_{5}-\mathrm{C}_{1}=\mathrm{O}_{2}$ and $\mathrm{O}_{17}-\mathrm{C}_{13}-\mathrm{C}_{3}=\mathrm{O}_{4}$ dihedral angles.

The calculated geometries for all three conformers are given in Table 1. From the analysis of these data the following conclusions can be extracted:

(a) According to the calculations, the most stable conformer for an isolated $\alpha$-furil molecule is analogous to that found in the crystalline state by X-ray diffraction. ${ }^{21}$ Moreover, the $\mathrm{O}=\mathrm{C}-\mathrm{C}=\mathrm{O}$ intercarbonyl dihedral angle is predicted to be larger for the single molecule $\left(153.1^{\circ}\right)$ than in the crystalline phase $\left(130.9^{\circ 21}\right)$. This result is expected taking into consideration the stabilization of more polar conformations (corresponding to smaller intercarbonyl dihedral angles) in the crystalline state.

(b) The intercarbonyl angle in the three conformers decreases in the order I > II > III. There are two main effects justifying this result: (i) the aforementioned stabilizing $\mathrm{CH} \cdots \mathrm{O}$ attractive interaction associated with the $\mathrm{H}-\mathrm{C}=\mathrm{C}-\mathrm{C}-\mathrm{C}=\mathrm{O}$ six-membered rings, which tend to be favoured by a planar arrangement of the molecule, is present twice in conformer I, only once in II and absent in III [note that the putative identical interaction associated with the
Table 1 Optimized [B3LYP/6-311++G(d,p)] geometries for the three conformers of $\alpha$-furil ${ }^{a}$

\begin{tabular}{llll}
\hline Bond length $/$ pm & I & II & III \\
\hline $\mathrm{C}_{1}=\mathrm{O}_{2} / \mathrm{C}_{3}=\mathrm{O}_{4}$ & 121.8 & $122.0 / 121.5$ & 121.8 \\
$\mathrm{C}_{1}-\mathrm{C}_{3}$ & 154.9 & 154.4 & 154.4 \\
$\mathrm{C}_{1}-\mathrm{C}_{5} / \mathrm{C}_{3}-\mathrm{C}_{13}$ & 145.8 & $145.7 / 145.7$ & 145.6 \\
$\mathrm{C}_{5}=\mathrm{C}_{6} / \mathrm{C}_{13}=\mathrm{C}_{14}$ & 137.6 & $137.3 / 137.4$ & 137.1 \\
$\mathrm{C}_{5}-\mathrm{O}_{9} / \mathrm{C}_{13}-\mathrm{O}_{17}$ & 137.3 & $137.1 / 136.9$ & 137.2 \\
$\mathrm{C}_{6}-\mathrm{C}_{7} / \mathrm{C}_{14}-\mathrm{C}_{15}$ & 142.0 & $142.0 / 142.1$ & 142.1 \\
$\mathrm{C}_{6}-\mathrm{H}_{10} / \mathrm{C}_{14}-\mathrm{H}_{18}$ & 107.6 & $107.8 / 107.7$ & 107.8 \\
$\mathrm{C}_{7}=\mathrm{C}_{8} / \mathrm{C}_{15}=\mathrm{C}_{16}$ & 136.6 & $136.7 / 136.6$ & 136.7 \\
$\mathrm{C}_{7}-\mathrm{H}_{11} / \mathrm{C}_{15}-\mathrm{H}_{19}$ & 107.8 & $107.8 / 107.8$ & 107.8 \\
$\mathrm{C}_{8}-\mathrm{O}_{9} / \mathrm{C}_{16}-\mathrm{O}_{17}$ & 134.6 & $134.7 / 134.8$ & 134.9 \\
$\mathrm{C}_{8}-\mathrm{H}_{12} / \mathrm{C}_{16}-\mathrm{H}_{20}$ & 107.8 & $107.8 / 107.8$ & 107.7 \\
& & & \\
\hline
\end{tabular}

\section{Angle ${ }^{\circ}$}

$\mathrm{O}_{2}=\mathrm{C}_{1}-\mathrm{C}_{3} / \mathrm{O}_{4}=\mathrm{C}_{3}-\mathrm{C}_{1}$

$\mathrm{O}_{2}=\mathrm{C}_{1}-\mathrm{C}_{5} / \mathrm{O}_{4}=\mathrm{C}_{3}-\mathrm{C}_{13}$

$\mathrm{C}_{3}-\mathrm{C}_{1}-\mathrm{C}_{5} / \mathrm{C}_{1}-\mathrm{C}_{3}-\mathrm{C}_{13}$

$\mathrm{C}_{1}-\mathrm{C}_{5}=\mathrm{C}_{6} / \mathrm{C}_{3}-\mathrm{C}_{13}=\mathrm{C}_{14}$

$\mathrm{C}_{1}-\mathrm{C}_{5}-\mathrm{O}_{9} / \mathrm{C}_{3}-\mathrm{C}_{13}-\mathrm{O}_{17}$

$\mathrm{C}_{6}=\mathrm{C}_{5}-\mathrm{O}_{9} / \mathrm{C}_{14}=\mathrm{C}_{13}-\mathrm{O}_{17}$

$\mathrm{C}_{5}=\mathrm{C}_{6}-\mathrm{C}_{7} / \mathrm{C}_{13}=\mathrm{C}_{14}-\mathrm{C}_{15}$

$\mathrm{C}_{5}=\mathrm{C}_{6}-\mathrm{H}_{10} / \mathrm{C}_{13}=\mathrm{C}_{14}-\mathrm{H}_{18}$

$\mathrm{C}_{7}-\mathrm{C}_{6}-\mathrm{H}_{10} / \mathrm{C}_{15}-\mathrm{C}_{14}-\mathrm{H}_{18}$

$\mathrm{C}_{6}-\mathrm{C}_{7}=\mathrm{C}_{8} / \mathrm{C}_{14}-\mathrm{C}_{15}=\mathrm{C}_{16}$

$\mathrm{C}_{6}-\mathrm{C}_{7}-\mathrm{H}_{11} / \mathrm{C}_{14}-\mathrm{C}_{15}-\mathrm{H}_{19}$

$\mathrm{C}_{8}=\mathrm{C}_{7}-\mathrm{H}_{11} / \mathrm{C}_{16}=\mathrm{C}_{15}-\mathrm{H}_{19}$

$\mathrm{C}_{7}=\mathrm{C}_{8}-\mathrm{O}_{9} / \mathrm{C}_{15}=\mathrm{C}_{16}-\mathrm{O}_{17}$

$\mathrm{C}_{7}=\mathrm{C}_{8}-\mathrm{H}_{12} / \mathrm{C}_{15}=\mathrm{C}_{16}-\mathrm{H}_{20}$

$\mathrm{O}_{9}-\mathrm{C}_{8}-\mathrm{H}_{12} / \mathrm{O}_{17}-\mathrm{C}_{16}-\mathrm{H}_{20}$

$\mathrm{C}_{5}-\mathrm{O}_{9}-\mathrm{C}_{8} / \mathrm{C}_{13}-\mathrm{O}_{17}-\mathrm{C}_{16}$

120.7
122.9
116.4
134.6
116.1
109.3
106.6
125.4
128.0
105.9
127.6
126.5
111.1
133.0
115.9
107.1

$120.0 / 119.5$

$122.0 / 124.4$

$117.9 / 116.0$

$130.8 / 133.1$

$119.6 / 117.4$

$109.6 / 109.5$

$106.5 / 106.5$

$125.3 / 125.7$

$128.2 / 127.7$

$106.0 / 105.9$

$127.7 / 127.6$

$126.4 / 126.5$

$110.9 / 111.0$

$133.1 / 133.1$

$116.0 / 115.9$

$107.0 / 107.1$

118.8

123.0

118.0

131.9

118.4

109.7

106.4

125.3

128.2

106.1

127.6

126.3

110.8

133.1

116.0

107.0

\section{Dihedral angle $/^{\circ}$}

$\mathrm{O}_{2}=\mathrm{C}_{1}-\mathrm{C}_{3}=\mathrm{O}_{4}$

$\mathrm{O}_{2}=\mathrm{C}_{1}-\mathrm{C}_{3}-\mathrm{C}_{13} / \mathrm{O}_{4}=\mathrm{C}_{3}-\mathrm{C}_{1}-\mathrm{C}_{5}$

$\mathrm{C}_{5}-\mathrm{C}_{1}-\mathrm{C}_{3}-\mathrm{C}_{13}$

$\mathrm{O}_{2}=\mathrm{C}_{1}-\mathrm{C}_{5}=\mathrm{C}_{6} / \mathrm{O}_{4}=\mathrm{C}_{3}-\mathrm{C}_{13}=\mathrm{C}_{14}$

$\mathrm{O}_{2}=\mathrm{C}_{1}-\mathrm{C}_{5}-\mathrm{O}_{9} / \mathrm{O}_{4}=\mathrm{C}_{3}-\mathrm{C}_{13}-\mathrm{O}_{17}$

$\mathrm{C}_{3}-\mathrm{C}_{1}-\mathrm{C}_{5}=\mathrm{C}_{6} / \mathrm{C}_{1}-\mathrm{C}_{3}-\mathrm{C}_{13}=\mathrm{C}_{14}$

$\mathrm{C}_{3}-\mathrm{C}_{1}-\mathrm{C}_{5}-\mathrm{O}_{9} / \mathrm{C}_{1}-\mathrm{C}_{3}-\mathrm{C}_{13}-\mathrm{O}_{17}$

$\mathrm{C}_{1}-\mathrm{C}_{5}=\mathrm{C}_{6}-\mathrm{C}_{7} / \mathrm{C}_{3}-\mathrm{C}_{13}=\mathrm{C}_{14}-\mathrm{C}_{15}$

$\mathrm{C}_{1}-\mathrm{C}_{5}=\mathrm{C}_{6}-\mathrm{H}_{10} / \mathrm{C}_{3}-\mathrm{C}_{13}=\mathrm{C}_{14}-\mathrm{H}_{18}$

$\mathrm{O}_{9}-\mathrm{C}_{5}=\mathrm{C}_{6}-\mathrm{C}_{7} / \mathrm{O}_{17}-\mathrm{C}_{13}=\mathrm{C}_{14}-\mathrm{C}_{15}$

$\mathrm{O}_{9}-\mathrm{C}_{5}=\mathrm{C}_{6}-\mathrm{H}_{10} / \mathrm{O}_{17}-\mathrm{C}_{13}=\mathrm{C}_{14}-\mathrm{H}_{18}$

$\mathrm{C}_{1}-\mathrm{C}_{5}-\mathrm{O}_{9}-\mathrm{C}_{8} / \mathrm{C}_{3}-\mathrm{C}_{13}-\mathrm{O}_{17}-\mathrm{C}_{16}$

$\mathrm{C}_{6}=\mathrm{C}_{5}-\mathrm{O}_{9}-\mathrm{C}_{8} / \mathrm{C}_{14}=\mathrm{C}_{13}-\mathrm{O}_{17}-\mathrm{C}_{16}$

$\mathrm{C}_{5}=\mathrm{C}_{6}-\mathrm{C}_{7}=\mathrm{C}_{8} / \mathrm{C}_{13}=\mathrm{C}_{14}-\mathrm{C}_{15}=\mathrm{C}_{16}$

$\mathrm{C}_{5}=\mathrm{C}_{6}-\mathrm{C}_{7}-\mathrm{H}_{11} / \mathrm{C}_{13}=\mathrm{C}_{14}-\mathrm{C}_{15}-\mathrm{H}_{19}$

$\mathrm{H}_{10}-\mathrm{C}_{6}-\mathrm{C}_{7}=\mathrm{C}_{8} / \mathrm{H}_{18}-\mathrm{C}_{14}-\mathrm{C}_{15}=\mathrm{C}_{16}$

$\mathrm{H}_{10}-\mathrm{C}_{6}-\mathrm{C}_{7}-\mathrm{H}_{11} / \mathrm{H}_{18}-\mathrm{C}_{14}-\mathrm{C}_{15}-\mathrm{H}_{19}$

$\mathrm{C}_{6}-\mathrm{C}_{7}=\mathrm{C}_{8}-\mathrm{O}_{9} / \mathrm{C}_{14}-\mathrm{C}_{15}=\mathrm{C}_{16}-\mathrm{O}_{17}$

$\mathrm{C}_{6}-\mathrm{C}_{7}=\mathrm{C}_{8}-\mathrm{H}_{12} / \mathrm{C}_{14}-\mathrm{C}_{15}=\mathrm{C}_{16}-\mathrm{H}_{20}$

$\mathrm{H}_{11}-\mathrm{C}_{7}=\mathrm{C}_{8}-\mathrm{O}_{9} / \mathrm{H}_{19}-\mathrm{C}_{15}=\mathrm{C}_{16}-\mathrm{O}_{17}$

$\mathrm{H}_{11}-\mathrm{C}_{7}=\mathrm{C}_{8}-\mathrm{H}_{12} / \mathrm{H}_{19}-\mathrm{C}_{15}=\mathrm{C}_{16}-\mathrm{H}_{20}$

$\mathrm{C}_{7}=\mathrm{C}_{8}-\mathrm{O}_{9}-\mathrm{C}_{5} / \mathrm{C}_{15}=\mathrm{C}_{16}-\mathrm{O}_{17}-\mathrm{C}_{13}$

$\mathrm{H}_{12}-\mathrm{C}_{8}-\mathrm{O}_{9}-\mathrm{C}_{5} / \mathrm{H}_{20}-\mathrm{C}_{16}-\mathrm{O}_{17}-\mathrm{C}_{13}$

${ }^{a}$ See Fig. 1 for atom numbering.

$\mathrm{H}-\mathrm{C}=\mathrm{C}-\mathrm{C}=\mathrm{O}$ five-membered rings present in conformers II (one five-membered ring) and III (two) are not energetically efficient, as inferred from the long $\mathrm{CH} \cdots \mathrm{O}$ distances associated with this fragment]; (ii) the repulsions between the furan and carbonyl oxygen lone-electron pairs, which are stronger when the interaction is $1-5$ than when it is $1-4$ (1-5 and $1-4$ 
furanyl/carbonyl oxygen lone-electron pairs' repulsion are associated with the $\mathrm{H}-\mathrm{C}=\mathrm{C}-\mathrm{C}-\mathrm{C}=\mathrm{O}$ six and $\mathrm{H}-\mathrm{C}=\mathrm{C}-\mathrm{C}=\mathrm{O}$ five-membered rings, respectively - see also Fig. 1).

(c) A consideration of the value of the intercarbonyl dihedral angle in $\alpha$-furil with those found in other $\alpha$-dicarbonyl molecules, such as diacetyl $\left(\mathrm{CH}_{3}-\mathrm{C}(=\mathrm{O})-\mathrm{C}(=\mathrm{O})-\mathrm{CH}_{3}\right)$, benzil, $\alpha$-pyridil, 1-phenyl-1,2-propanedione and mesityl (1,2dimesitylethane-1,2-dione) provides some interesting comparisons. The first fact to note is that, with a single exception (discussed in detail below), in all these compounds the two halves of the molecule tend to have a maximum number of atoms of the substituent bonded to the carbonyl carbon in the plane of the carbonyl group. ${ }^{7,8,11,12,19,21,31,32}$ This trend results from the attempt to maximize resonance (or hyperconjugation, in the case of the methyl substituent) between the carbonyl group and the substituent. On the other hand, in this kind of molecules the conjugation at the intercarbonyl bond has been found to be minimal, ${ }^{7-12}$ which in fact justifies the great conformational flexibility associated with this bond. This point is discussed in more detail below. Among the molecules mentioned above, diacetyl and mesityl are the two extreme cases: in the first molecule, steric repulsions due to the methyl substituents are minimal and the molecule is transplanar $\left(\mathrm{O}=\mathrm{C}-\mathrm{C}=\mathrm{O}\right.$ intercarbonyl angle equal to $\left.180^{\circ}\right),^{7}$ while in the second the substituents are sterically arranged such that the mesityl groups are forced out of the carbonyl planes and become nearly perpendicular to them. ${ }^{31,32}$ Very interestingly, mesityl assumes a quasi-cis-conformation around the intercarbonyl bond in its minimum energy conformation, ${ }^{31,32}$ a result that stresses the importance of repulsive interactions involving the substituents and the carbonyl groups in this type of molecule whenever the two fragments are close together. Excluding mesityl, among the other molecules under analysis benzil is the one that exhibits the smallest intercarbonyl dihedral angle $\left(c a .100^{\circ}\right)$. This indicates that in this molecule a larger value of the intercarbonyl dihedral angle would lead to $\mathrm{CH}$... O distances (involving the ortho hydrogen atoms of the phenyl groups and the oxygen atoms) excessively short, leading to the $\mathrm{CH}$. O O interactions becoming repulsive. As expected, in this regard 1-phenyl-1,2-propanedione $\left(\mathrm{O}=\mathrm{C}-\mathrm{C}=\mathrm{O}: c a \cdot 130.0^{\circ 12}\right)$ lies between diacetyl and benzil. On the other hand, $\alpha$-pyridil has a somewhat larger intercarbonyl dihedral than benzil ( $\mathrm{ca} .120^{\circ 11,19}$ ), because in its minimum energy conformation the carbon-by nitrogen substitutions eliminate two of the $\mathrm{CH}$.. O destabilizing steric interactions and the new $1-4 \mathrm{~N} / \mathrm{O}$ lone-electron pair repulsions are comparatively less significant. Finally, after diacetyl, $\alpha$-furil has the largest intercarbonyl angle among all the molecules here considered. This can be easily explained taking into account that in this molecule, like in $\alpha$-pyridil, only two $\mathrm{CH}$... $\mathrm{O}$ interactions are present and, contrarily to what happens in $\alpha$-pyridil, these interactions can be attractive for larger intercarbonyl dihedral angles due to the more favourable geometry associated with the five-membered furanyl ring (when compared with those associated with the sixmembered pyridyl or phenyl rings present in $\alpha$-pyridil and benzil, which make the $\mathrm{CH}$.. O distances comparatively shorter in these molecules than in $\alpha$-furil for the same intercarbonyl angle). (d) The comparison of the $\mathrm{C}-\mathrm{C}$ bond lengths in $\alpha$-furil is particularly useful to extract information regarding the extension of conjugation between the different parts of the molecule. As could have been anticipated, the $\mathrm{C}_{7}=\mathrm{C}_{8}$ (and $\mathrm{C}_{15}=\mathrm{C}_{16}$ ) are the shortest carbon-carbon bonds in the molecule (136.6 pm), being significantly more localized than the carbon-carbon bonds in the phenyl rings of benzil and 1-phenyl-1,2-propanedione (where these bond lengths range from $138.8 \mathrm{pm}$ to 140.5 $\mathrm{pm}^{8,12}$ ). This result is in accordance with the well-known relatively weak conjugation within the furan moiety. ${ }^{33-35} \mathrm{On}$ the other hand, the $\mathrm{C}_{5}=\mathrm{C}_{6}$ (and $\mathrm{C}_{13}=\mathrm{C}_{14}$ ) bonds in $\alpha$-furil are considerably longer (137.1 to $137.6 \mathrm{pm}$, depending on the particular conformer) than $\mathrm{C}_{7}=\mathrm{C}_{8}$ (and $\mathrm{C}_{15}=\mathrm{C}_{16}$ ), mainly because of the conjugation between the furan and nearest carbonyl group. The $\mathrm{C}_{1}-\mathrm{C}_{5}$ (and $\mathrm{C}_{3}-\mathrm{C}_{13}$ ) bonds, connecting the $\mathrm{O}=\mathrm{C}-\mathrm{C}=\mathrm{O}$ group to the furanyl rings (145.6-145.8 pm) were found to be shorter than in benzil and 1-phenyl-1,2propanedione $\left(148.7 \mathrm{pm}^{8,12}\right)$, indicating that in $\alpha$-furil the conjugation between the substituents and the dicarbonyl moiety is more important than in these two analogous compounds. Note also that the $\mathrm{C}_{5}=\mathrm{C}_{6} / \mathrm{C}_{13}=\mathrm{C}_{14}$ and $\mathrm{C}_{1}-\mathrm{C}_{5} / \mathrm{C}_{3}-\mathrm{C}_{13}$ bond lengths do not differ significantly among the different conformers of $\alpha$-furil (see Table 1), indicating that the extension of the conjugation between the furanyl and carbonyl in the various forms is identical. The longest $\mathrm{C}-\mathrm{C}$ bond in the molecule is the central intercarbonyl $\mathrm{C}-\mathrm{C}$ bond, which is $154.4-154.9 \mathrm{pm}$ long (depending slightly on the conformer). Such a bond length is characteristic of a non-conjugated $\mathrm{C}-\mathrm{C}$ single bond and this result follows the trend already noticed for other simple $\alpha$ dicarbonyls, like diacetyl, benzil and 1-phenyl-1,2-propanedione, for example. ${ }^{7,8,12}$ Indeed, it has been repeatedly demonstrated that the $\pi$-conjugation between the two carbonyl groups in the $\mathrm{O}=\mathrm{C}-\mathrm{C}=\mathrm{O}$ fragment is minimal, the dominant forces determining the intercarbonyl $\mathrm{C}-\mathrm{C}$ bond length being those associated with the repulsions between the positively charged carbonyl carbon atoms (acting essentially through the $\sigma$-electron system). Besides being in agreement with the observed large conformational flexibility around the $\mathrm{C}-\mathrm{C}$ intercarbonyl bond in $\alpha$-dicarbonyls, this result is also in accordance with the relative facility of these molecules to suffer cleavage of this bond [e.g., the bond energies of $\mathrm{C}-\mathrm{C}$ intercarbonyl bond in diacetyl and benzil are only $c a .280 \mathrm{~kJ} \mathrm{~mol}^{-1}$, which is quite a small value in comparison, for instance, with the bond energies of the $\mathrm{CH}_{3}-\mathrm{C}$ bond in acetone and acetophenone ( $c a .320$ and $360 \mathrm{~kJ}$ $\mathrm{mol}^{-1}$, respectively) or the $\mathrm{C}-\mathrm{C}$ bond in ethane $(376.0 \mathrm{~kJ}$ $\left.\left.\mathrm{mol}^{-1}\right)\right]^{7,8,36-43}$

(e) The calculated relative values for the $\mathrm{O}_{2}=\mathrm{C}_{1}-\mathrm{C}_{3}$ (and $\left.\mathrm{O}_{4}=\mathrm{C}_{3}-\mathrm{C}_{1}\right)$ and $\mathrm{C}_{3}-\mathrm{C}_{1}-\mathrm{C}_{5}\left(\mathrm{C}_{1}-\mathrm{C}_{3}-\mathrm{C}_{13}\right)$ angles in $\alpha$-furil also deserve an additional comment, since they are the parameters that differ most among the various conformers. In conformer I, the calculated values for these angles are 120.7 and $116.4^{\circ}$, respectively, while in conformer III they become smaller $\left(118.8^{\circ}\right)$ and larger $\left(118.0^{\circ}\right)$. The values of these angles can be correlated with the stronger steric interactions between the lone-electron pairs of furanyl and carbonyl oxygens in conformer III, which tend to increase the pair of angles $\mathrm{C}_{3}-\mathrm{C}_{1}-\mathrm{C}_{5}$ / $\mathrm{C}_{1}-\mathrm{C}_{3}-\mathrm{C}_{13}$ at expenses of the $\mathrm{O}_{2}=\mathrm{C}_{1}-\mathrm{C}_{3} / \mathrm{O}_{4}=\mathrm{C}_{3}-\mathrm{C}_{1}$ angles. In the case of conformer II, these trends are also roughly observed, though the asymmetry of the molecule introduces 
further structural complexity that makes the analysis less straightforward.

The relatively close energies predicted by the calculations for the three conformers of $\alpha$-furil suggested the possibility of trapping all the three forms in the cryogenic matrices, since they could be expected to be present in significant amounts in the gaseous phase at the relevant temperatures. At room temperature, the populations of the three conformers (I, II, III), estimated taking into consideration the calculated relative energies, are 79, 15 and $6 \%$, respectively. On the other hand, within the temperature range accessible in practical terms (the lower temperature is determined by the sublimation temperature of the compound and the higher temperature by the experimental set up configuration and temperature of decomposition of the compound), $c a$. 400-450 K, the estimated populations are $65-62,24-26$ and $11-12 \%$, respectively. Hence, all conformers could be expected to be observable in the matrices, unless the barriers for conformational interconversion were low enough to allow conformational cooling to take place extensively during matrix deposition. ${ }^{44}$

The DFT(B3LYP)/6-311 + + G(d,p) calculated energy barriers for conformational interconversion in $\alpha$-furil are given in Table 2. A three-dimensional map representing the calculated transition states structures for conformational isomerization between the conformers is shown in Fig. 2. In this figure, the axes correspond to the three conformationally relevant dihedral angles, $\mathrm{O}_{2}=\mathrm{C}_{1}-\mathrm{C}_{5}-\mathrm{O}_{6}, \quad \mathrm{O}_{4}=\mathrm{C}_{3}-\mathrm{C}_{13}-\mathrm{O}_{17}$ and $\mathrm{O}_{2}=\mathrm{C}_{1}-\mathrm{C}_{3}=\mathrm{O}_{4}$. Interconversion between the two conformers of $C_{2}$ symmetry (I and III) and the $C_{1}$ conformer (II) could, in principle, be expected to take place through two different transition states, depending on the direction of the internal rotation. This was found to be true for the interconversion between conformers II and III, however, for the interconversion between I and II only one transition state could be located, the internal rotations performed in both directions around the $\mathrm{C}_{1}-\mathrm{C}_{5}$ leading to the same transition state structure with the intercarbonyl angle nearly equal to $180^{\circ}$. All transition states have energies at least $c a .40 \mathrm{~kJ} \mathrm{~mol}^{-1}$ above the higher energy conformer that they interconnect. Direct interconversion between I and III, by concerted internal rotation around the $\mathrm{O}_{2}=\mathrm{C}_{1}-\mathrm{C}_{5}-\mathrm{O}_{6}$ and $\mathrm{O}_{4}=\mathrm{C}_{3}-\mathrm{C}_{13}-\mathrm{O}_{17}$ axes (preserving the $C_{2}$ symmetry along the rotation) occurs through transition state TS2 (or a symmetry related transition

Table 2 DFT(B3LYP) $/ 6-311++\mathrm{G}(\mathrm{d}, \mathrm{p})$ calculated energies $(\Delta E / \mathrm{kJ}$ $\mathrm{mol}^{-1}$ ) of the transition state structures (TS\#) for interconversion between the energy minima in the potential energy hypersurface of $\alpha$ furil $^{a}$

\begin{tabular}{llll}
\hline & I & II & III \\
\hline I & & 47.2 TS1 & 93.2 TS2 \\
II & 40.6 TS1 & & 44.3 TS3 \\
& & & 46.5 TS4 \\
III & 85.7 TS2 & 43.3 TS3 & \\
& & 45.6 TS4 &
\end{tabular}

${ }^{a} \Delta E$ corresponds to the energy barriers from the bottom of the potential energy minima. The entries in the table correspond to the reactant given as row heading and product as column heading.

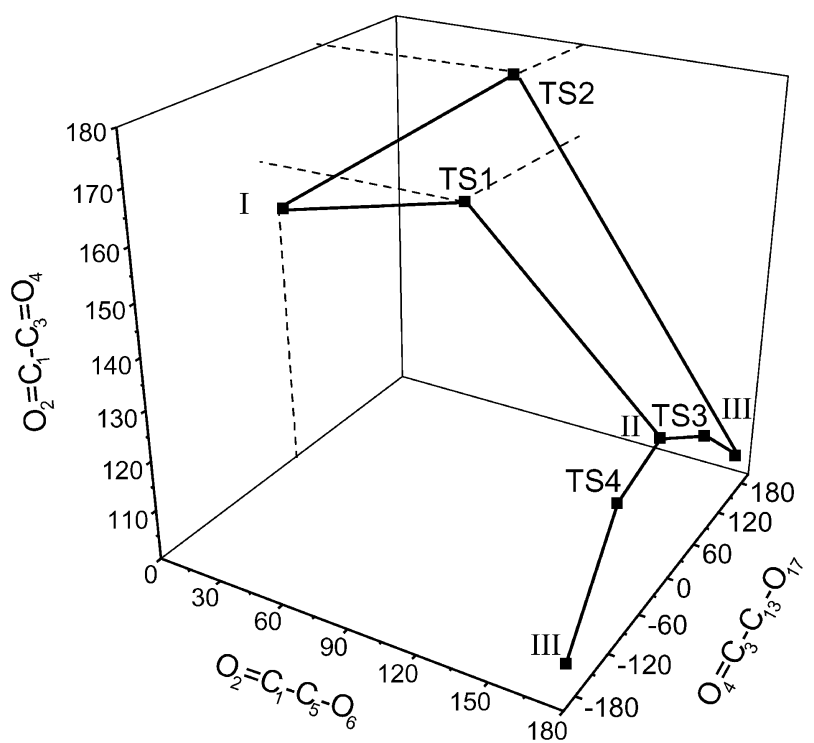

Fig. 2 Three-dimensional map representing the calculated [DFT(B3LYP) $/ 6-311++\mathrm{G}(\mathrm{d}, \mathrm{p})]$ transition state structures for conformational isomerization between the conformers of $\alpha$-furil. The axes correspond to the three conformationally relevant dihedral angles, and are shown in the domains $\mathrm{O}_{2}=\mathrm{C}_{1}-\mathrm{C}_{5}-\mathrm{O}_{6}:\left[0^{\circ}, 180^{\circ}\right], \mathrm{O}_{4}=\mathrm{C}_{3}-\mathrm{C}_{13}-\mathrm{O}_{17}$ : $\left[-180^{\circ}, 180^{\circ}\right], \mathrm{O}_{2}=\mathrm{C}_{1}-\mathrm{C}_{3}=\mathrm{O}_{4}:\left[100^{\circ}, 180^{\circ}\right]$.

state) whatever the direction of the movement, since at TS2 the intercarbonyl angle is necessarily equal to $180^{\circ}$ (trans-). This transition state has a relative energy of $c a .85 \mathrm{~kJ} \mathrm{~mol}^{-1}$ relative to conformer III. All the energy barriers for conformational isomerization in $\alpha$-furil are therefore predicted by the calculations to be large enough to prevent conformational isomerization at the temperatures of the matrix isolation experiments.

In summary, considering both the relative conformational energies and barriers to conformational isomerization obtained theoretically, it could be expected that the three conformers of $\alpha$-furil should be observable in the low temperature matrices, with their trapped populations being approximately those existing in the gas phase equilibrium prior to deposition. The range of nozzle temperatures accessible to experiment (400-450 K), though not very wide, afforded the possibility of experimental identification of bands due to single conformers through comparison of the relative band intensities in the spectra of matrices obtained using different nozzle temperatures. On the other hand annealing of the matrices (either after or during deposition - by changing the substrate temperature) could be expected not to be efficient in promoting significant conformational cooling, since the barriers to conformational isomerization appear to be excessively high. ${ }^{44,45}$

\section{Infrared spectroscopy: matrix isolation}

$\alpha$-Furil molecule has 54 fundamental vibrations, all of them active in the infrared. Definition of the internal coordinates adopted in the vibrational analysis is provided in Tables S1 and S2 (ESI $\dagger$ ), respectively for the $C_{2}$ symmetry conformers (I and III) and $C_{1}$ form (II). The calculated wavenumbers, infrared intensities and potential energy distributions resulting from normal mode analysis, carried out for the three conformers, are presented in Tables S3-S5 (ESI $\dagger$ ). Fig. 3 displays 
the spectra of $\alpha$-furil isolated in both solid argon and xenon (as-deposited matrices; nozzle temperature $413 \mathrm{~K}$; substrate temperature: argon, $10 \mathrm{~K}$, xenon, $20 \mathrm{~K}$ ), together with the theoretical spectrum resulting from summing the calculated spectra for the three conformers. In the latter spectrum, the contributions from each conformer were scaled by their relative populations at $413 \mathrm{~K}$, estimated from the calculated relative energies and assuming the Boltzmann distribution. As required, the conformers degeneracy was taken into consideration in these calculations. Table 3 presents the assignments for the fundamental bands, which was strongly aided by the excellent agreement between the experimental and the calculated data. Fig. 4-8 compare the experimental spectra obtained in argon matrices under different conditions with the calculated spectra (for individual conformers and the sum

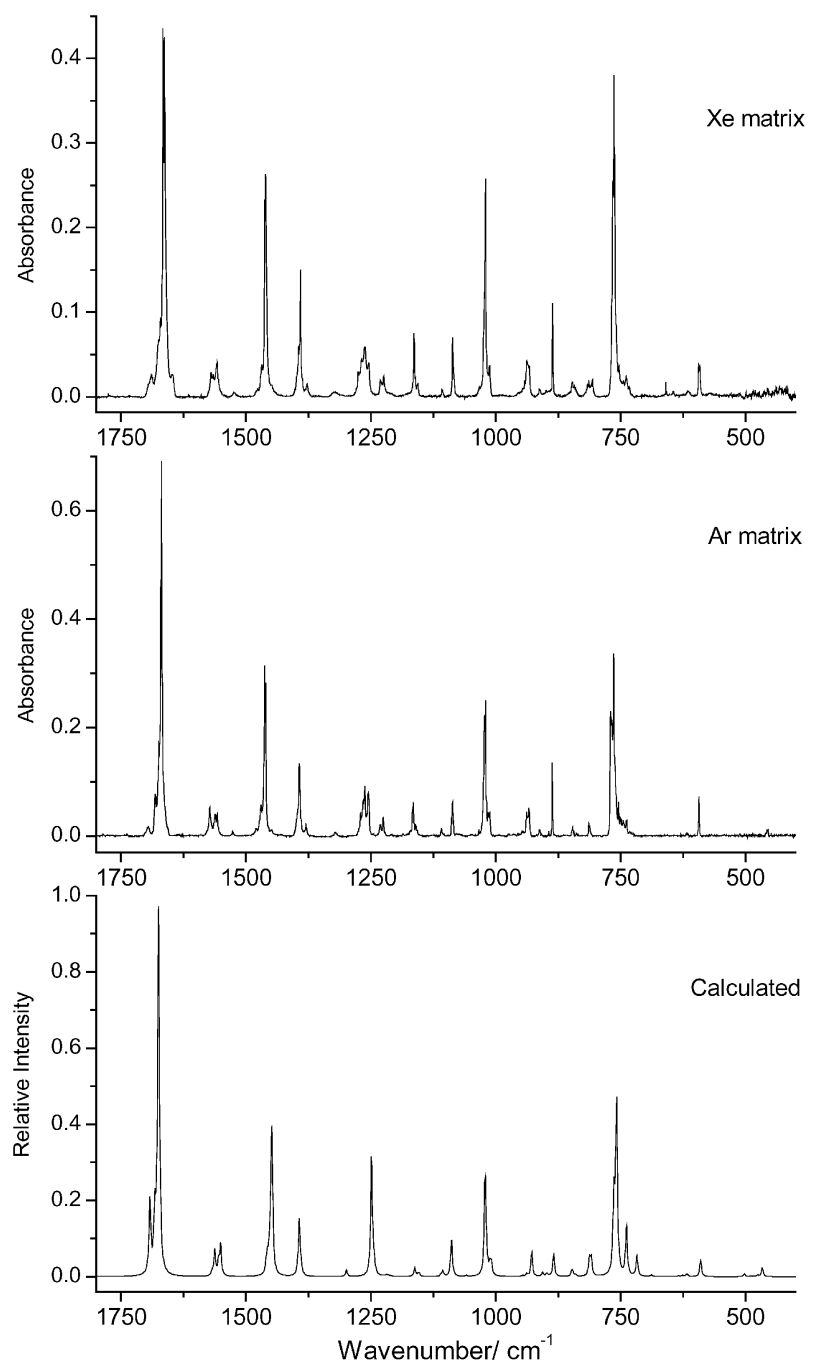

Fig. 3 IR spectra of $\alpha$-furil isolated in solid argon and xenon (asdeposited matrices; nozzle temperature $413 \mathrm{~K}$; substrate temperature: argon, $10 \mathrm{~K}$, xenon, $20 \mathrm{~K}$ ) and the theoretical spectrum obtained by adding the calculated spectra for the three conformers of the molecule. In the latter spectrum, the contributions from each conformer were scaled by their relative populations at $413 \mathrm{~K}$ as estimated from the calculated relative energies and assuming the Boltzmann distribution. As required, the conformers degeneracy was taken into consideration in these calculations. spectrum, synthesized as described above). The two experimental spectra shown in the figure were obtained with all conditions kept unchanged except the temperature of the $\alpha$ furil vapour (nozzle temperature, $T_{\mathrm{N}}$ ) and the temperature of the substrate during deposition $\left(T_{\mathrm{S}}\right)$ as described. These two variables were chosen in such a way that in one experiment $\mathrm{A}$ $\left(T_{\mathrm{N}}=393 \mathrm{~K} ; T_{\mathrm{S}}=25 \mathrm{~K}\right)$ the population of the most stable conformer could be expected to be comparatively larger than in experiment $\mathrm{B}\left(T_{\mathrm{N}}=413 \mathrm{~K} ; T_{\mathrm{S}}=10 \mathrm{~K}\right)$.

The spectra obtained in experiments $\mathrm{A}$ and $\mathrm{B}$ differ substantially, in accordance with the trapping of more than one conformer in the matrices. Annealing experiments were undertaken after the matrices were deposited until the temperature reached $40 \mathrm{~K}$, but no changes could be noticed except those ascribable to aggregation in the latter stages of annealing. Annealing to a higher temperature $(80 \mathrm{~K})$ was also carried out for the compound isolated in xenon, with identical results (annealing to beyond this temperature led to extensive aggregation of the compound). These results are in agreement with the existence of high energy barriers separating the different conformers of $\alpha$-furil and preventing conformational isomerization taking place in the matrices within the accessible temperature ranges. According to Barnes, ${ }^{45}$ an energy barrier of $c a .25 \mathrm{~kJ}$ $\mathrm{mol}^{-1}$ is high enough to be overcome at a temperature of $80 \mathrm{~K}$ and, therefore, the annealing results clearly demonstrated that the conformational energy barriers in $\alpha$-furil should be at least as large as this value. Indeed, these results are consistent with the calculated energy barriers shown in Table 2, which are all larger than this limit value. Note that the calculated energy barriers are in fact high enough to also prevent conformational cooling taking place during matrix deposition. Under these conditions, the real temperature at the growing matrix is slightly higher than that measured at the sample holder due to release by the host atoms of excessive energy during crystallization. However, in our set up the difference between the effective temperature of the growing matrix and that measured at the sample holder is only a few Kelvin ${ }^{44,46}$ and then, during deposition, the effective temperatures were always much lower than those necessary to allow for conformational isomerization of $\alpha$-furil to occur. Also in agreement with these conclusions is the fact that, in the spectra of the as-deposited matrices, the relative intensities of bands ascribable to different conformers are very similar upon going from argon to xenon matrices (see Fig. 3). Furthermore, it is also worth noticing that in the above discussion calculated energy barriers for the molecule in a vacuum were used. In fact, the physical presence of the matrix material can be expected to change these barriers somewhat, most likely increasing them, thus further supporting the conclusions presented above.

As mentioned above, the assignment of the bands to individual conformers relied essentially on the comparison between the spectra obtained in experiments $\mathrm{A}$ and $\mathrm{B}$ and between these results and the calculated spectra for individual conformers. The calculations predicted that in the different conformers most of the vibrations should give rise to bands at nearly coincident frequencies (see Tables S3-S5†). In agreement with these results, several bands in the observed spectra must be assigned to more than one conformer (see Fig. 4-8 and Table 3), and the great majority of those assigned to a single conformer overlap partially with bands due to other 
Table 3 Experimental and calculated vibrational data for the monomer of $\alpha$-furil ${ }^{a}$

\begin{tabular}{|c|c|c|c|c|c|}
\hline \multicolumn{2}{|l|}{ Experimental } & \multicolumn{4}{|l|}{ Calculated } \\
\hline Ar matrix/wavenumber & Xe matrix/wavenumber & Conformer & Approximate description & Wavenumber $^{b}$ & Intensity \\
\hline \multirow[t]{5}{*}{$3152.4(w)$} & & I & $\nu(\mathrm{C}-\mathrm{H} 1)$ as & 3209.0 & 6.5 \\
\hline & & & $\nu(\mathrm{C}-\mathrm{H} 2)$ as & 3199.9 & 0.8 \\
\hline & & II & $\nu(\mathrm{C}-\mathrm{H} 2)^{\prime}$ & 3195.9 & 1.1 \\
\hline & & & $\nu(\mathrm{C}-\mathrm{H} 2)$ & 3191.3 & 1.1 \\
\hline & & III & $\nu(\mathrm{C}-\mathrm{H} 2)$ as & 3190.7 & 1.8 \\
\hline \multirow[t]{4}{*}{$3141.2(w)$} & & I & $\nu(\mathrm{C}-\mathrm{H} 3)$ as & 3177.2 & 2.3 \\
\hline & & II & $\nu(\mathrm{C}-\mathrm{H} 3)^{\prime}$ & 3177.2 & 1.4 \\
\hline & & & $\nu(\mathrm{C}-\mathrm{H} 3)$ & 3176.2 & 0.8 \\
\hline & & III & $\nu(\mathrm{C}-\mathrm{H} 3)$ as & 3175.9 & 1.2 \\
\hline $1695.9(2 \times 887)(w)$ & $1689.5(2 \times 886)(w)$ & & & & \\
\hline \multirow[t]{2}{*}{$1681.3(\mathrm{w})$} & $1675.4(\mathrm{w})$ & II & $\nu(\mathrm{C}=\mathrm{O})^{\prime}$ & 1692.3 & 265.3 \\
\hline & & III & $\nu(\mathrm{C}=\mathrm{O}) \mathrm{s}$ & 1692.5 & 183.9 \\
\hline \multirow[t]{2}{*}{$1674.6(\mathrm{~m})$} & $1671.5(\mathrm{~m})$ & I & $\nu(\mathrm{C}=\mathrm{O}) \mathrm{s}$ & 1681.7 & 48.6 \\
\hline & & III & $\nu(\mathrm{C}=\mathrm{O})$ as & 1683.1 & 345.9 \\
\hline 1669.1/1670.1 (S) & 1666.1/1663.1 (S) & I & $\nu(\mathrm{C}=\mathrm{O})$ as & 1675.2 & 560.2 \\
\hline $1667.3(\mathrm{sh})$ & 1660.9 (sh) & II & $\nu(\mathrm{C}=\mathrm{O})$ & 1673.2 & 302.6 \\
\hline $1578.4(w)$ & $1575.9(\mathrm{sh})$ & III & $\nu($ ring 3$) \mathrm{s}$ & 1568.2 & 36.6 \\
\hline \multirow[t]{2}{*}{$1572.7(w)$} & $1570.0(w)$ & II & $\nu($ ring 3$)$ & 1562.3 & 63.4 \\
\hline & $1565.4(w)$ & III & $\nu($ ring 3$)$ as & 1562.8 & 146.3 \\
\hline $1561.8(w)$ & $1559.8(\mathrm{sh})$ & II & $\nu(\text { ring } 3)^{\prime}$ & 1554.9 & 54.7 \\
\hline \multirow[t]{2}{*}{ 1557.9/1557.1 (w) } & $1557.7(w)$ & I & $\nu($ ring 3$) \mathrm{s}$ & 1554.9 & 2.1 \\
\hline & & & $\nu($ ring 3$)$ as & 1550.8 & 51.3 \\
\hline \multirow[t]{2}{*}{$1526.9(2 \times 764)(w)$} & $1524.4(2 \times 762)(w)$ & & & & \\
\hline & $1522.4(2 \times 763)(w)$ & & & & \\
\hline $1479.6(w)$ & $1476.8(w)$ & III & $\nu($ ring 2$) \mathrm{s}$ & 1459.1 & 90.3 \\
\hline $1470.3(w)$ & $1468.4(w)$ & II & $\nu(\text { ring } 2)^{\prime}$ & 1456.9 & 60.2 \\
\hline \multirow[t]{3}{*}{$1462.4(\mathrm{~S})$} & $1462.1(\mathrm{~m})$ & I & $\nu$ (ring 2$)$ as & 1448.1 & 214.2 \\
\hline & & II & $\nu($ ring 2$)$ & 1450.2 & 181.6 \\
\hline & & III & $\nu$ (ring 2$)$ as & 1452.6 & 185.9 \\
\hline $1460.7(\mathrm{~S})$ & $1460.9(\mathrm{~m})$ & I & $\nu$ (ring 2$)$ as & 1448.1 & 214.2 \\
\hline $1448.4(2 \times 738)(w)$ & $1448.5(2 \times 733)(\mathrm{w})$ & & & & \\
\hline $1397.8(w)$ & $1398.4(\mathrm{sh})$ & II & $\nu(\text { ring } 4)^{\prime}$ & 1394.5 & 37.1 \\
\hline \multirow[t]{2}{*}{$1392.7(\mathrm{~m})$} & $1395.2(\mathrm{w}) / 1391.0(\mathrm{~m})$ & I & $\nu($ ring 4$) \mathrm{s}$ & 1396.1 & 3.3 \\
\hline & & & $\nu$ (ring 4$)$ as & 1393.2 & 85.5 \\
\hline $1389.6(\mathrm{w})$ & $1387.4(\mathrm{sh})$ & II & $\nu($ ring 4$)$ & 1390.2 & 19.5 \\
\hline $1379.8(w)$ & $1377.8(w)$ & III & $\nu($ ring 4$) \mathrm{s}$ & 1388.7 & 4.5 \\
\hline & & & $\nu$ (ring 4$)$ as & 1387.5 & 17.8 \\
\hline $1321.2(w)$ & $1323.7(w)$ & I & $\nu\left(\mathrm{C}-\mathrm{C}_{\alpha}\right) \mathrm{s}$ & 1299.6 & 3.2 \\
\hline & & II & $\nu\left(\mathrm{C}-\mathrm{C}_{\alpha}\right)$ & 1298.5 & 21.8 \\
\hline & & III & $\nu($ ring 4$) \mathrm{s}$ & 1388.7 & 4.5 \\
\hline & & & $\nu($ ring 4$)$ as & 1387.5 & 17.8 \\
\hline $1274.1(w)$ & $1278.9(\mathrm{sh})$ & II & $\nu\left(\mathrm{C}-\mathrm{C}_{\alpha}\right)^{\prime d}$ & 1248.9 & 116.3 \\
\hline $1271.0(\mathrm{w})$ & $1275.4(\mathrm{w})$ & & & & \\
\hline $1267.0(\mathrm{sh})$ & $1272.8(\mathrm{sh})$ & & & & \\
\hline $1265.7(w)$ & $1269.2(\mathrm{w})$ & & & & \\
\hline $1263.7(w)$ & & & & & \\
\hline $1261.1 / 1258.4(\mathrm{w})$ & $1262.2(\mathrm{w})$ & I & $\nu\left(\mathrm{C}-\mathrm{C}_{\alpha}\right)$ as ${ }^{e}$ & 1248.3 & 160.4 \\
\hline $1255.4 / 1254.2(w)$ & $1254.2(w)$ & III & $\nu\left(\mathrm{C}-\mathrm{C}_{\alpha}\right)$ as ${ }^{f}$ & 1243.1 & 123.1 \\
\hline $1231.0(\mathrm{w})$ & $1230.9(w)$ & II & $\delta(\mathrm{C}-\mathrm{H} 1)^{\prime}$ & 1223.6 & 2.2 \\
\hline $1225.2(w)$ & $1224.3(w)$ & I & $\delta(\mathrm{C}-\mathrm{H} 1) \mathrm{s}$ & 1219.8 & 0.3 \\
\hline & & & $\delta(\mathrm{C}-\mathrm{H} 1)$ as & 1219.2 & 1.7 \\
\hline & & II & $\delta(\mathrm{C}-\mathrm{H} 1)$ & 1216.3 & 3.4 \\
\hline & & III & $\delta(\mathrm{C}-\mathrm{H} 1) \mathrm{s}$ & 1216.5 & 3.0 \\
\hline & & & $\delta(\mathrm{C}-\mathrm{H} 1)$ as & 1211.2 & 10.1 \\
\hline $1209.2(2 \times 617)(w)$ & N.o. & & & & \\
\hline $1171.2(\mathrm{w})$ & $1167.4(\mathrm{sh})$ & II & $\nu(\text { ring } 5)^{\prime}$ & 1163.1 & 4.5 \\
\hline $1166.9(\mathrm{sh}) / 1165.3(\mathrm{w})$ & $1163.7(w)$ & I & $\nu$ (ring 5) as & 1162.3 & 12.7 \\
\hline $1160.3(w)$ & $1160.3(w)$ & II & $\nu($ ring 5$)$ & 1155.5 & 10.1 \\
\hline $1157.2(w)$ & $1157.3 / 1156.1(\mathrm{w})$ & III & $\nu($ ring 5$) \mathrm{s}$ & 1155.4 & 0.1 \\
\hline & & & $\nu$ (ring 5) as & 1153.6 & 25.3 \\
\hline $1108.4(w)$ & $1107.6(w)$ & II & $\nu($ ring 1$)$ & 1105.9 & 24.7 \\
\hline & & III & $\nu(\operatorname{ring} 1) \mathrm{s}$ & 1109.5 & 19.6 \\
\hline 1088.5/1086.4 (w) & $1086.5(\mathrm{w}) / 1083.9(\mathrm{sh})$ & I & $\delta(\mathrm{C}-\mathrm{H} 2)$ as & 1088.6 & 48.9 \\
\hline & & II & $\delta(\mathrm{C}-\mathrm{H} 2)^{\prime}$ & 1088.4 & 26.5 \\
\hline & & III & $\nu($ ring 1$)$ as & 1088.3 & 33.2 \\
\hline $1033.8(w)$ & $1032 . /(\mathrm{W})$ & I & $\delta(\mathrm{C}-\mathrm{H} 3)$ as & 1021.2 & 161.7 \\
\hline $1022.5 / 1020.9(\mathrm{~S})$ & $1023.9 / 1022.1(\mathrm{sn}) / 1020 . /(\mathrm{m}))$ & & & & \\
\hline $1019.0(\mathrm{sh})$ & N.o. & II & $\delta(\mathrm{C}-\mathrm{H} 3)^{\prime}$ & 1018.5 & 83.1 \\
\hline $1015.7(w)$ & $1016.3(\mathrm{sh})$ & III & $\delta(\mathrm{C}-\mathrm{H} 3)$ as & 1011.8 & 104.0 \\
\hline
\end{tabular}


Table 3 (continued)

\begin{tabular}{|c|c|c|c|c|c|}
\hline \multicolumn{2}{|l|}{ Experimental } & \multicolumn{4}{|l|}{ Calculated } \\
\hline Ar matrix/wavenumber & Xe matrix/wavenumber & Conformer & Approximate description & Wavenumber $^{b}$ & Intensity \\
\hline \multirow[t]{2}{*}{$1013.4 / 1012.5(\mathrm{w})$} & \multirow[t]{2}{*}{$1012.7(w)$} & I & $\delta(\mathrm{C}-\mathrm{H} 2) \mathrm{s}$ & 1008.8 & 3.8 \\
\hline & & II & $\delta(\mathrm{C}-\mathrm{H} 2)$ & 1008.9 & 40.5 \\
\hline $974.6(2 \times 502)(w)$ & N.o. & & & & \\
\hline $946.5(w)$ & $946.0(\mathrm{sh})$ & III & $\delta(\mathrm{C}-\mathrm{H} 2)$ as & 946.6 & 9.4 \\
\hline $938.4(w)$ & $941.9 / 938.2(\mathrm{w})$ & II & $\nu(\operatorname{ring} 1)^{\prime}$ & 938.3 & 11.5 \\
\hline 936.2/933.7 (w) & 935.1/933.4 (w) & I & $\nu($ ring 1$)$ as & 928.2 & 39.3 \\
\hline \multirow[t]{2}{*}{$912.0(w)$} & \multirow[t]{2}{*}{$911.7(w)$} & I & $\delta(\operatorname{ring} 1) \mathrm{s}$ & 906.7 & 2.2 \\
\hline & & II & $\delta(\operatorname{ring} 1)$ & 905.9 & 13.2 \\
\hline \multirow[t]{2}{*}{$894.1(w)$} & \multirow[t]{2}{*}{$899.5(w)$} & \multirow[t]{2}{*}{ I } & $\gamma(\mathrm{C}-\mathrm{H} 3)$ as & 898.8 & 1.4 \\
\hline & & & $\gamma(\mathrm{C}-\mathrm{H} 3) \mathrm{s}$ & 898.0 & 3.6 \\
\hline \multirow[t]{7}{*}{887.1 (m) } & \multirow[t]{7}{*}{$886.2(\mathrm{~m})$} & \multirow[t]{2}{*}{ I } & $\delta($ ring 2$)$ as & 884.3 & 26.5 \\
\hline & & & $\delta($ ring 2$) \mathrm{s}$ & 883.2 & 0.8 \\
\hline & & \multirow[t]{3}{*}{ II } & $\gamma(\mathrm{C}-\mathrm{H} 3)^{\prime}$ & 888.9 & 1.4 \\
\hline & & & $\delta(\operatorname{ring} 2)$ & 884.1 & 4.8 \\
\hline & & & $\delta(\operatorname{ring} 2)^{\prime}$ & 883.3 & 14.9 \\
\hline & & \multirow{2}{*}{ III } & $\delta(\operatorname{ring} 2)$ as & 883.4 & 12.7 \\
\hline & & & $\delta($ ring 2$) \mathrm{s}$ & 883.1 & 1.3 \\
\hline 847.6 (sh) & $847.0(\mathrm{w})$ & II & $\gamma(\mathrm{C}-\mathrm{H} 2)$ & 849.2 & 7.4 \\
\hline \multirow[t]{2}{*}{$846.0(\mathrm{sh})$} & \multirow[t]{2}{*}{$842.6(w)$} & III & $\gamma(\mathrm{C}-\mathrm{H} 2)$ as & 847.4 & 20.5 \\
\hline & & I & $\gamma(\mathrm{C}-\mathrm{H} 2) \mathrm{s}$ & 847.2 & 7.1 \\
\hline $843.9(w)$ & $842.6(\mathrm{w})$ & I & $\gamma(\mathrm{C}-\mathrm{H} 2) \mathrm{s}$ & 847.2 & 7.1 \\
\hline $838.1(w)$ & $840.7(w)$ & II & $\gamma(\mathrm{C}-\mathrm{H} 2)^{\prime}$ & 840.7 & 6.5 \\
\hline \multirow[t]{2}{*}{$838.1(w)$} & $838.7(w)$ & III & $\gamma(\mathrm{C}-\mathrm{H} 2) \mathrm{s}$ & 840.4 & 4.4 \\
\hline & $\int 816.1(w)$ & & & & \\
\hline $813.4(w)$ & & III & $\gamma(\mathrm{C}=\mathrm{O})$ as & 813.4 & 76.4 \\
\hline & $813.6(\mathrm{~W})$ & I & $\gamma(\mathrm{C}=\mathrm{O})$ as & 809.0 & 27.1 \\
\hline & $806.4(w)$ & II & $\gamma(\mathrm{C}=\mathrm{O})^{\prime}$ & 811.9 & 51.3 \\
\hline & & I & $\gamma(\mathrm{C}=\mathrm{O})$ as & 809.0 & 27.1 \\
\hline $770.0(\mathrm{~m})$ & 765.7 (sh) & I & $\gamma(\mathrm{C}-\mathrm{H} 1) \mathrm{s}^{g}$ & 764.2 & 121.2 \\
\hline & & & $\gamma(\mathrm{C}-\mathrm{H} 1)$ as & 763.7 & 3.7 \\
\hline 768.8/764.3 (S) & 763.4/762.2 (S) & I & $\delta($ ring 1$)$ as & 758.2 & 243.6 \\
\hline $766.0(\mathrm{sh})$ & & II & $\gamma(\mathrm{C}-\mathrm{H} 1)^{\prime}$ & 760.8 & 76.7 \\
\hline 761.4 (sh) & & III & $\gamma(\mathrm{C}-\mathrm{H} 1) \mathrm{s}$ & 758.3 & 74.1 \\
\hline $754.6(w)$ & $753.6(w)$ & II & $\gamma(\mathrm{C}-\mathrm{H} 1)$ & 759.3 & 45.3 \\
\hline $750.7(w)$ & $744.1(w)$ & III & $\gamma(\mathrm{C}-\mathrm{H} 1)$ as & 757.8 & 45.3 \\
\hline $748.9(\mathrm{w})$ & $739.1(\mathrm{w})$ & II & $\delta(\operatorname{ring} 1)^{\prime}$ & 738.3 & 224.2 \\
\hline $745.1(\mathrm{w})$ & 736.7 (sh) & III & $\nu(\mathrm{C}-\mathrm{C})$ & 739.8 & 16.3 \\
\hline $738.4(w)$ & $733.0(w)$ & II & $\nu(\mathrm{C}-\mathrm{C})$ & 718.2 & 9.9 \\
\hline & & III & $\delta($ ring 1$)$ as & 717.3 & 203.6 \\
\hline N.o. & $659.7(w)$ & I & $\tau($ ring 2$) \mathrm{s}$ & 634.6 & 1.5 \\
\hline N.o. & $644.9(w)$ & II & $\tau(\text { ring } 2)^{\prime}$ & 626.0 & 5.4 \\
\hline $616.0(\mathrm{w})$ & $614.7(w)$ & I & $\tau($ ring 2$)$ as & 617.2 & 2.8 \\
\hline & & II & $\tau($ ring 2$)$ & 618.5 & 2.1 \\
\hline & & III & $\tau($ ring 2$)$ as & 619.1 & 3.6 \\
\hline & & & $\tau(\operatorname{ring} 2) \mathrm{s}$ & 618.9 & 4.9 \\
\hline $593.5(\mathrm{w})$ & $594.0 / 591.4(\mathrm{w})$ & I & $\tau($ ring 1$) \mathrm{s}$ & 590.0 & 18.9 \\
\hline & & & $\tau($ ring 1$)$ as & 589.5 & 0.4 \\
\hline & & II & $\tau(\operatorname{ring} 1)^{\prime}$ & 590.4 & 14.7 \\
\hline & & & $\tau(\operatorname{ring} 1)$ & 588.9 & 2.3 \\
\hline & & III & $\tau($ ring 1$) \mathrm{s}$ & 590.8 & 9.9 \\
\hline & & & $\tau($ ring 1$)$ as & 589.3 & 3.7 \\
\hline $511.8(\mathrm{w})$ & $512.6(\mathrm{w})$ & I & $\omega$ (ring) as & 502.3 & 4.8 \\
\hline $458.7(w)$ & N.o. & II & $\delta(\mathrm{C}=\mathrm{O})^{\prime}$ & 489.5 & 2.8 \\
\hline & & & $\gamma(\mathrm{C}=\mathrm{O})$ & 475.8 & 8.0 \\
\hline & & III & $\gamma(\mathrm{C}=\mathrm{O}) \mathrm{s}$ & 483.1 & 4.1 \\
\hline & & & $\delta(\mathrm{C}=\mathrm{O})$ as & 481.9 & 1.4 \\
\hline 456.8 & $458.7(w)$ & I & $\gamma(\mathrm{C}=\mathrm{O}) \mathrm{s}$ & 466.1 & 14.7 \\
\hline
\end{tabular}

${ }^{a}$ Wavenumbers in $\mathrm{cm}^{-1}$; calculated intensities in $\mathrm{km} \mathrm{mol}^{-1} ; \nu$, bond stretching; $\delta$, bending; $\gamma$, rocking; $\omega$, wagging; $\tau$, torsion; s, symmetric; as, asymmetric; N.o., not observed. See Tables S1 and S2 (ESI $\dagger$ ) for definition of internal coordinates and Tables S3 to S5 for potential energy distributions. ${ }^{b}$ Scaled (0.978). ${ }^{c}$ Experimental intensities are presented in qualitative terms: $\mathrm{S}=$ strong, $\mathrm{m}=\mathrm{medium}$; $\mathrm{w}=\mathrm{weak}$, sh $=$ shoulder. ${ }^{d}$ Fermi resonance with $\delta(\mathrm{C}-\mathrm{H} 1)^{\prime}+\delta(\mathrm{C}=\mathrm{O})^{\prime} .{ }^{e}$ Fermi resonance with $\gamma(\mathrm{C}-\mathrm{H} 1)$ as $+\gamma(\mathrm{C}=\mathrm{O})$ s. ${ }^{f}$ Fermi resonance with $\gamma(\mathrm{C}-\mathrm{H} 1)$ as $+\gamma(\mathrm{C}=\mathrm{O}) \mathrm{s} .{ }^{g}$ Fermi resonance with $\gamma(\mathrm{C}=\mathrm{O}) \mathrm{s}+\delta(\mathrm{C}=\mathrm{O})$ as.

forms. However, the global analysis of the spectra left no doubt about the presence in the matrices of the three conformers. The results shown in Fig. 4-8 also unequivocally demonstrate that the relative conformational populations estimated from calculations fit nicely those observed trapped in the matrices and that, as expected, in experiment $\mathrm{A}$ the 

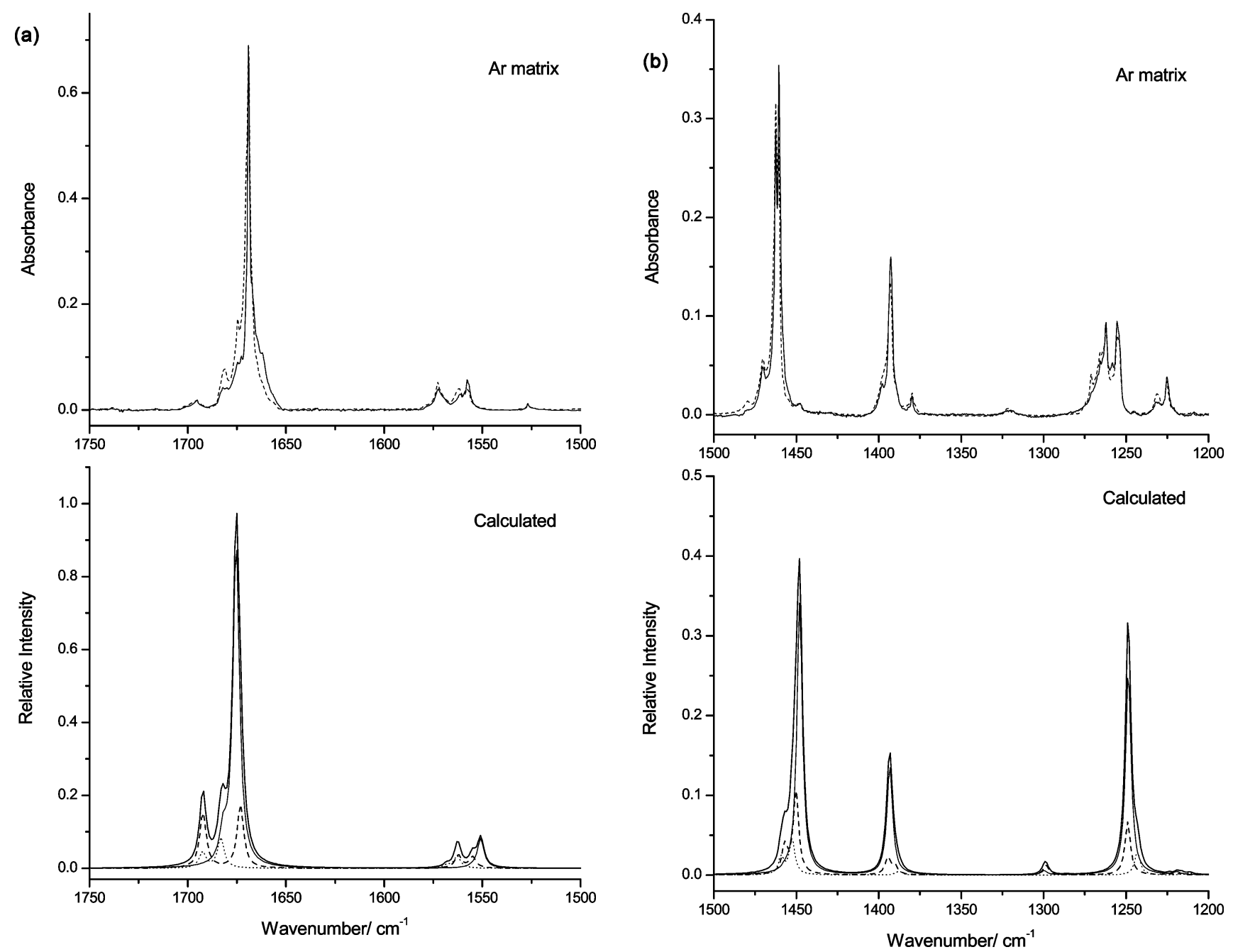

Fig. 4 Upper panel: IR spectra of $\alpha$-furil isolated in argon matrices. -: spectrum of the as-deposited matrix prepared using a nozzle temperature of $413 \mathrm{~K}$ and deposition temperature of $10 \mathrm{~K}$. --: spectrum of the as-deposited matrix prepared using a nozzle temperature of $393 \mathrm{~K}$ and deposition temperature of $25 \mathrm{~K}$. Lower panel: IR calculated spectra for individual conformers of $\alpha$-furil (-: $\mathbf{I} ;$--: II $\cdots$ : III). - : the spectrum obtained by adding the calculated spectra for the three conformers, weighted by their relative populations at $413 \mathrm{~K}$, estimated from the calculated relative energies and assuming the Boltzmann distribution (degeneracies of the conformers were taken into consideration in these calculations). Spectra are presented divided in different spectral ranges: (a) $1750-1500 \mathrm{~cm}^{-1}$.

bands ascribable to the most stable conformer (I) increase relative to those originating from the less stable forms (II and III) in accordance with the increased population of the conformational ground state when lower nozzle temperatures were used. This is clearly observed in all spectral regions shown in Fig. 4-8, though the agreement between the calculated and experimental data is slightly less good for the 950-800 $\mathrm{cm}^{-1}$ region (e.g., relative band intensities; see Fig. 7).

Under the premises resulting from the above conclusions, the detailed assignment of the spectra is straightforward. Two observations deserve further comment:

(a) Firstly, it is worth noting the systematic occurrence of matrix site band-splitting for modes that have a large

Fig. 5 Upper panel: IR spectra of $\alpha$-furil isolated in argon matrices. -: spectrum of the as-deposited matrix prepared using a nozzle temperature of $413 \mathrm{~K}$ and deposition temperature of $10 \mathrm{~K}$. --: spectrum of the as-deposited matrix prepared using a nozzle temperature of $393 \mathrm{~K}$ and deposition temperature of $25 \mathrm{~K}$. Lower panel: IR calculated spectra for individual conformers of $\alpha$-furil (-: I; --: II; $\cdots$ : III). - : the spectrum obtained by adding the calculated spectra for the three conformers, weighted by their relative populations at $413 \mathrm{~K}$, estimated from the calculated relative energies and assuming the Boltzmann distribution (degeneracies of the conformers were taken into consideration in these calculations). Spectra are presented in the spectral range: (b) $1500-1200 \mathrm{~cm}^{-1}$.

absorption cross-section. Naturally, this is particularly evident for the bands due to the most abundant conformer I [e.g., for $\nu(\mathrm{C}=\mathrm{O})$ as, $\nu$ (ring 2) as, $\nu(\mathrm{C}-\mathrm{H} 3)$ as, $\nu$ (ring 1$)$ as and $\delta$ (ring 1) as; see Table 3], since for II and III both the low intensity of the bands and their extensive overlap prevent a clear observation of this phenomenon in most cases. The observed band splitting demonstrates that a molecule of $\alpha$-furil can occupy different sites in both argon and xenon matrices. In addition, since in the annealing experiments only very small changes in the relative intensities of the site-split bands with temperature were observed, it can be concluded that the stability of the different matrix sites does not differ very much from each other. 


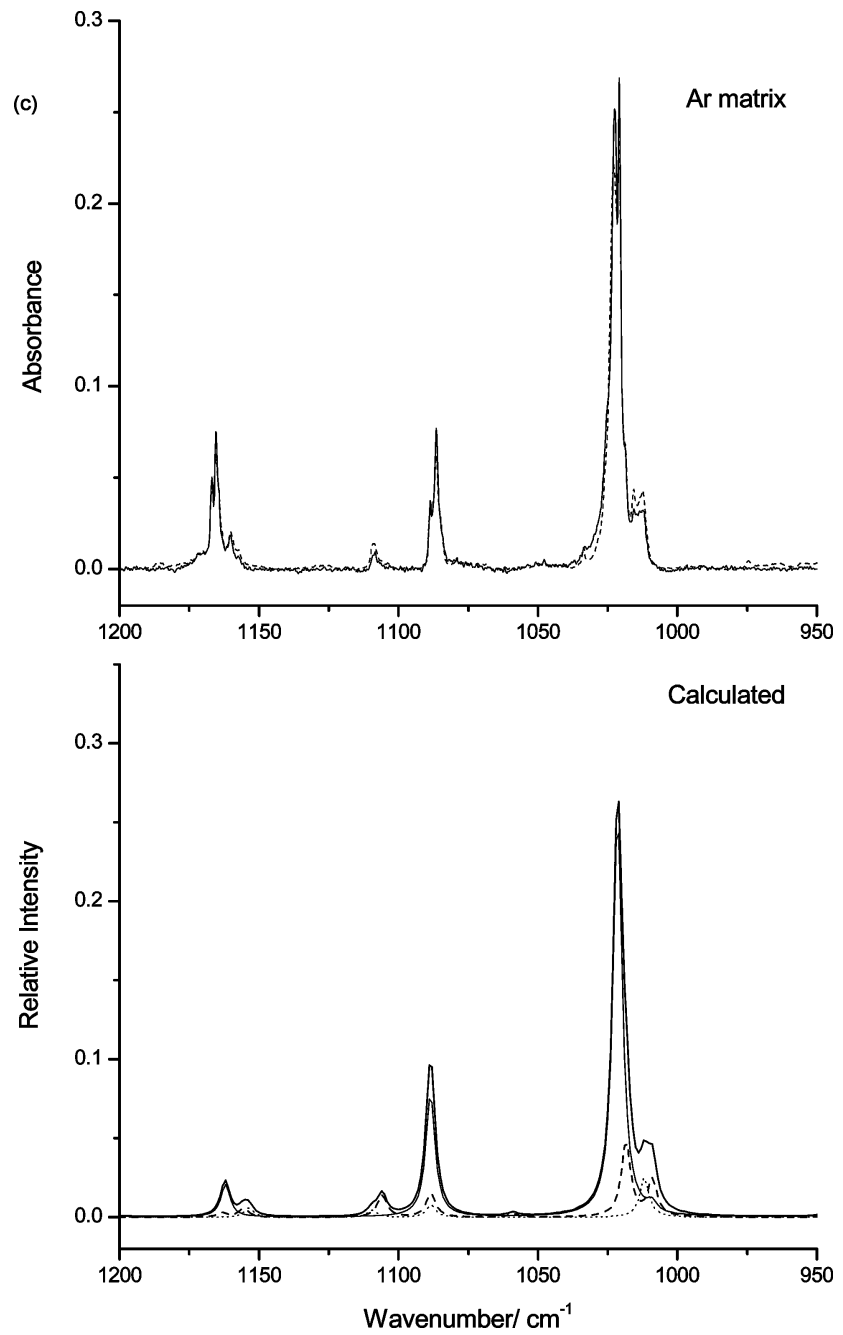

Fig. 6 Upper panel: IR spectra of $\alpha$-furil isolated in argon matrices. -: spectrum of the as-deposited matrix prepared using a nozzle temperature of $413 \mathrm{~K}$ and deposition temperature of $10 \mathrm{~K}$. --: spectrum of the as-deposited matrix prepared using a nozzle temperature of $393 \mathrm{~K}$ and deposition temperature of $25 \mathrm{~K}$. Lower panel: IR calculated spectra for individual conformers of $\alpha$-furil (-: I; --: II; $\cdots$ : III). - : the spectrum obtained by adding the calculated spectra for the three conformers, weighted by their relative populations at $413 \mathrm{~K}$, estimated from the calculated relative energies and assuming the Boltzmann distribution (degeneracies of the conformers were taken into consideration in these calculations). Spectra are presented in the spectral range: (c) $1200-950 \mathrm{~cm}^{-1}$.

(b) Secondly, it is interesting to note the occurrence of Fermi resonance interactions involving the $\nu\left(\mathrm{C}-\mathrm{C}_{\alpha}\right)$ as, $\delta$ (ring 1) as and $\gamma(\mathrm{C}-\mathrm{H} 1)$ fundamentals in all conformers [see Table 3 and Fig. 5 and 8)]. The most probable anharmonic vibrations coupled by the Fermi resonance interaction with the $\left[\nu\left(\mathbf{C}-\mathbf{C}_{\alpha}\right)\right.$ as $]$ fundamental are given in Table 3; according to the definition of coordinates provided in Tables $\mathrm{S} 1$ and $\mathrm{S} 2, \dagger$ the interacting combination tone is different in conformer II compared to I and III due to the different global symmetry of the conformers (nevertheless, the mode is, in all cases, a combination of a carbonyl and a $\mathrm{C}-\mathrm{H}$ deformational mode). On the other hand, the complex band structure observed in the

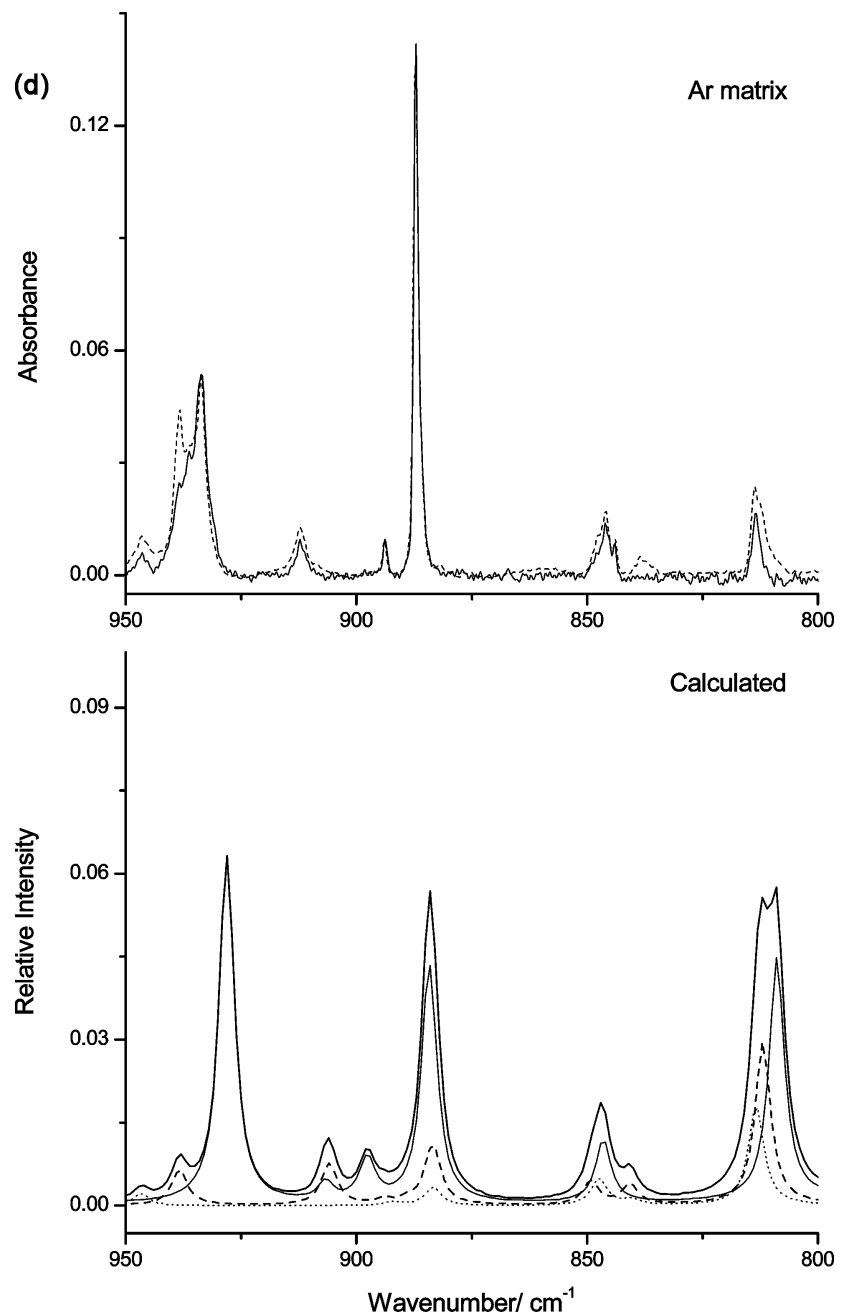

Fig. 7 Upper panel: IR spectra of $\alpha$-furil isolated in argon matrices. -: spectrum of the as-deposited matrix prepared using a nozzle temperature of $413 \mathrm{~K}$ and deposition temperature of $10 \mathrm{~K}$. --: spectrum of the as-deposited matrix prepared using a nozzle temperature of $393 \mathrm{~K}$ and deposition temperature of $25 \mathrm{~K}$. Lower panel: IR calculated spectra for individual conformers of $\alpha$-furil (-: I $\mathbf{I}$--: II; $\cdots$ : III). - : the spectrum obtained by adding the calculated spectra for the three conformers, weighted by their relative populations at $413 \mathrm{~K}$, estimated from the calculated relative energies and assuming the Boltzmann distribution (degeneracies of the conformers were taken into consideration in these calculations). Spectra are presented in the spectral range: (d) $950-800 \mathrm{~cm}^{-1}$.

$775-725 \mathrm{~cm}^{-1}$ region, where both $\delta($ ring 1$)$ as and $\gamma(\mathrm{C}-\mathrm{H} 1)$ modes absorb, does not allow for a detailed characterization of the Fermi resonance couplings involving these vibrations. Indeed, the assignment of this spectral region proposed in Table 3 shall be considered as tentative.

\section{Infrared spectroscopy: low temperature crystalline and glassy states}

Fig. 9 presents the IR spectra of $\alpha$-furil in the neat low temperature amorphous phase and crystalline state. The assignment of the recorded spectra is provided in Table 4. 

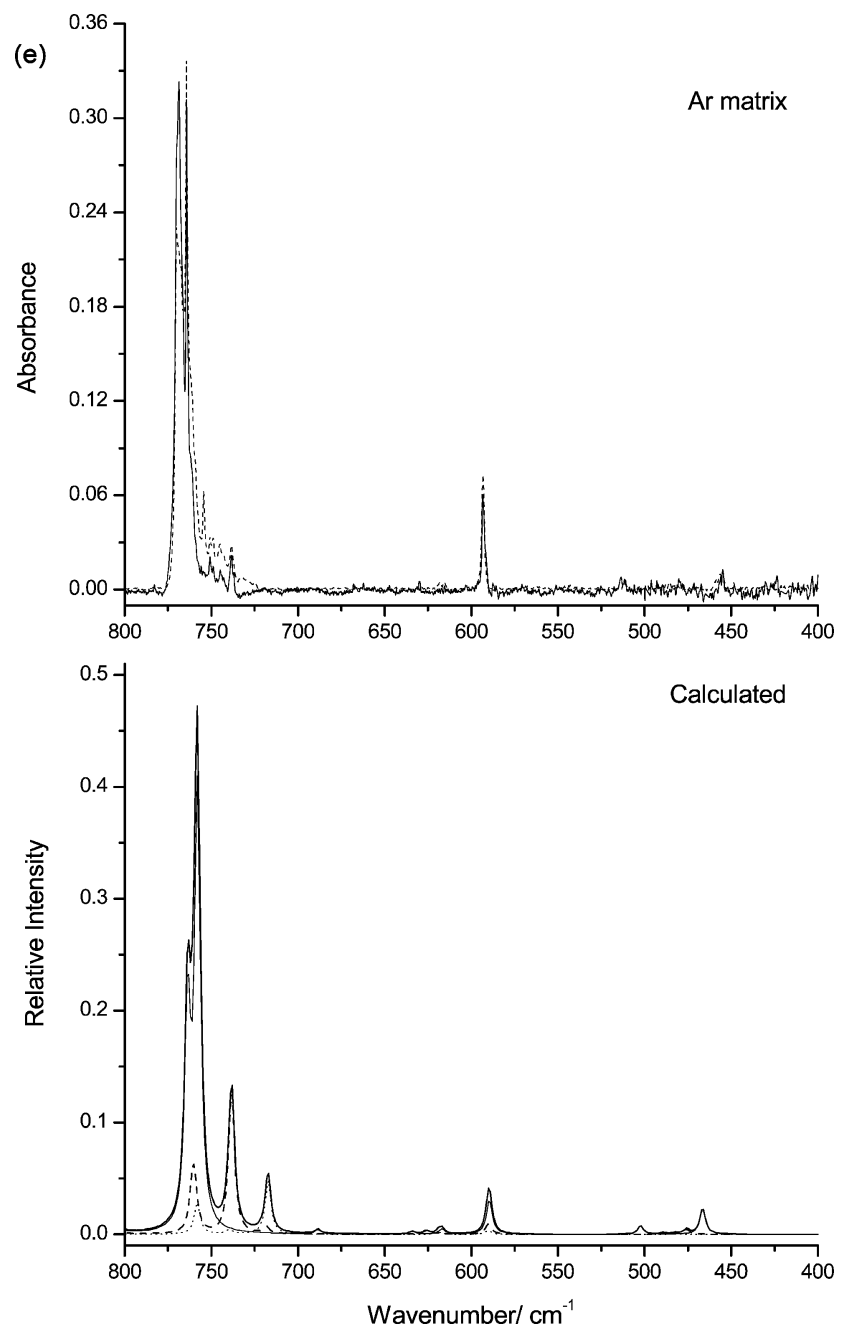

Fig. 8 Upper panel: IR spectra of $\alpha$-furil isolated in argon matrices. -: spectrum of the as-deposited matrix prepared using a nozzle temperature of $413 \mathrm{~K}$ and deposition temperature of $10 \mathrm{~K}$. --: spectrum of the as-deposited matrix prepared using a nozzle temperature of $393 \mathrm{~K}$ and deposition temperature of $25 \mathrm{~K}$. Lower panel: IR calculated spectra for individual conformers of $\alpha$-furil (-: I; --: II; $\cdots$ : III). —: the spectrum obtained by adding the calculated spectra for the three conformers, weighted by their relative populations at $413 \mathrm{~K}$, estimated from the calculated relative energies and assuming the Boltzmann distribution (degeneracies of the conformers were taken into consideration in these calculations). Spectra are presented in the spectral range: (e) $800-400 \mathrm{~cm}^{-1}$.

As expected, the spectrum of the amorphous phase is constituted by relatively wide bands, containing contributions from the three conformers of $\alpha$-furil present in the vapour prior to deposition of the solid layer. Nevertheless, the spectrum can be easily correlated with those obtained for the matrix-isolated compound (and also with the calculated data), which facilitates its detailed analysis and band assignment. The spectrum of the crystal is characterized essentially by the general multiplet structure exhibited by the bands, which can be attributed to crystal field splitting. However, in spite of the complexity due to this effect, the comparison of the spectra of the crystal and amorphous phases doubtlessly demonstrates
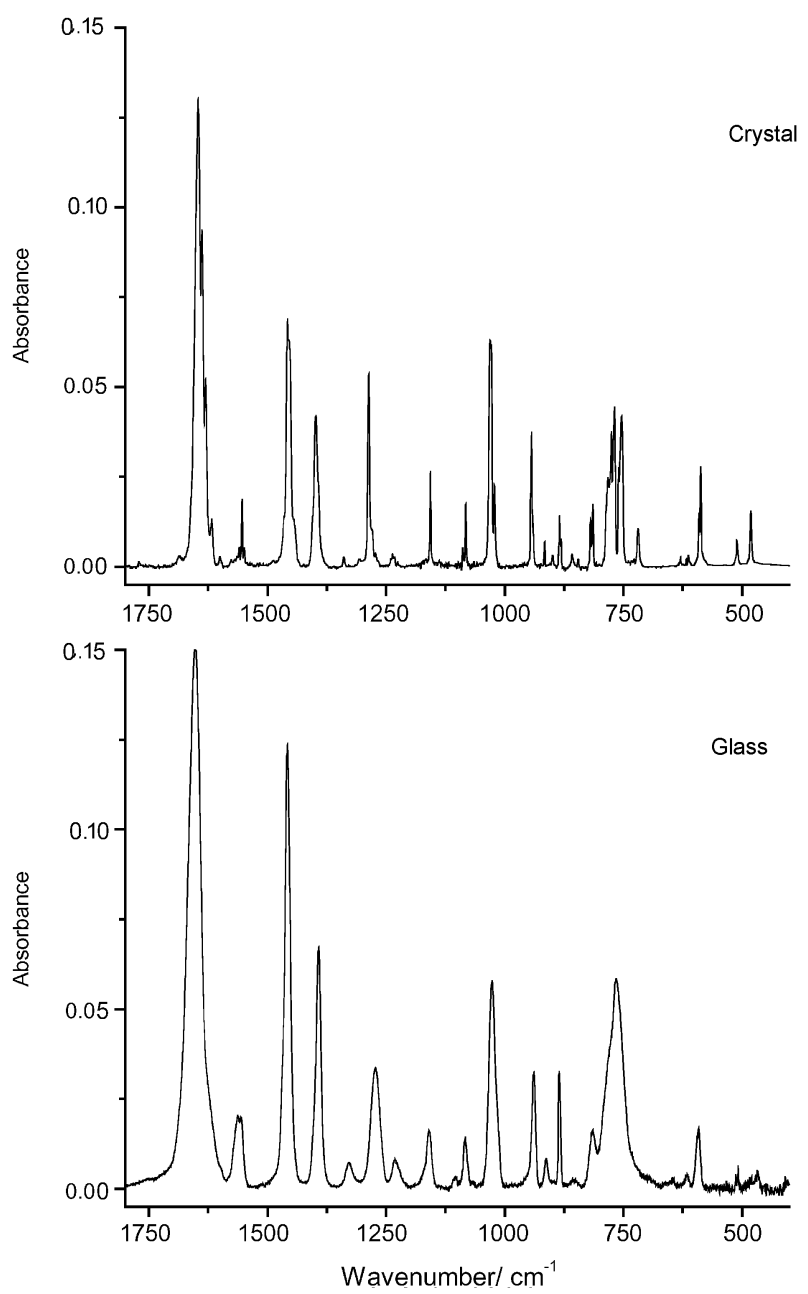

Fig. 9 IR spectra of $\alpha$-furil in the low temperature crystalline and glassy states (see the Materials and methods section for a detailed description of the experimental conditions).

that in the crystal the molecules exist in a unique conformation, identical to conformer $\mathbf{I}$, in agreement with the structural data obtained by X-ray. ${ }^{21}$ In fact, two mark bands of conformers II and III are observed in the spectrum of the glass at 1562.9 and $1105.3 \mathrm{~cm}^{-1}$ (see Fig. 9 and Table 4) - these are the only bands that can be safely assigned exclusively to these conformers; the remaining absorptions of these species, in the spectrum of the glass coincide with absorptions of the dominant conformer, I- and these bands are absent from the spectrum of the crystal.

On the whole, besides leading to a detailed assignment of the spectra of the crystal and low temperature amorphous states (Table 4), these studies provided an independent confirmation of (a) the presence in the vapour phase of more than one conformer, with form I being heavily predominant at $413 \mathrm{~K}$ (from the glassy state spectra alone it would not be possible to distinguish between conformers II and III), thus giving further support to the interpretation of the matrix-isolation spectroscopy data here presented, and (b) the presence in the crystalline state of only one form, which corresponds to the most stable conformer of the isolated molecule, fully confirming the previously reported X-ray data. ${ }^{21}$ 
Table 4 Observed wavenumbers of $\alpha$-furil in the low temperature glassy and crystalline states ${ }^{a}$

\begin{tabular}{|c|c|c|}
\hline \multirow[b]{2}{*}{$\begin{array}{l}\text { Approximate } \\
\text { description }\end{array}$} & \multicolumn{2}{|c|}{ Experimental } \\
\hline & $\begin{array}{l}\text { Glass } \\
(10 \mathrm{~K})^{b}\end{array}$ & $\begin{array}{l}\text { Crystal } \\
(10 \mathrm{~K})^{c}\end{array}$ \\
\hline$\nu(\mathrm{C}-\mathrm{H} 1)$ as & & 3153.7 \\
\hline$\nu(\mathrm{C}-\mathrm{H} 1) \mathrm{s}$ & & 3151.2 \\
\hline$\nu(\mathrm{C}-\mathrm{H} 2) \mathrm{s}$ & 3140.2 & 3145.6 \\
\hline$\nu(\mathrm{C}-\mathrm{H} 2)$ as & & 3136.1 \\
\hline$\nu(\mathrm{C}-\mathrm{H} 3) \mathrm{s}$ & & 3131.5 \\
\hline$\nu(\mathrm{C}-\mathrm{H} 3)$ as & 3125.0 & $\begin{array}{l}3120.1 \\
3113.6\end{array}$ \\
\hline & $l_{1653.6}^{1650^{d}}$ & $1646.8 / 1638.4 / 1630.5 / 1617.9$ \\
\hline $\begin{array}{l}\nu(\text { ring } 3)(\mathrm{II}) \\
\nu(\text { ring } 3) \mathrm{s} / \nu \text { (ring 3) as (III) }\end{array}$ & $\cdot \int 1562.9^{a}$ & \\
\hline$\nu($ ring 3$) \mathrm{s} / \nu($ ring 3$)$ as & 1555.6 & $1559.8 / 1555.6 / 1548.8$ \\
\hline$\nu(\operatorname{ring} 2) \mathrm{s}$ & 1467.8 & 1465.8 \\
\hline$\nu(\operatorname{ring} 2)$ as & 1458.1 & $1457.8 / 1454.7$ \\
\hline$\nu$ (ring 2$)$ as & N.o. & 1445.0 \\
\hline$\nu$ (ring 4$)$ as & 1392.2 & $1398.4 / 1393.2$ \\
\hline$\nu\left(\mathrm{C}-\mathrm{C}_{\alpha}\right) \mathrm{s}$ & 1329.0 & 1339.8 \\
\hline$\nu\left(\mathrm{C}-\mathrm{C}_{\alpha}\right)$ as & 1272.4 & $1306.5 / 1286.7 / 1279.7$ \\
\hline$\delta(\mathrm{C}-\mathrm{H} 1) \mathrm{s} / \delta(\mathrm{C}-\mathrm{H} 1)$ as & 1231.1 & $1237.0 / 1232.5 / 1225.9$ \\
\hline$\nu($ ring 5$)$ as & 1160.1 & 1157.4 \\
\hline$\nu($ ring 1$)($ II) & $1105.3^{d}$ & \\
\hline$\nu($ ring 1$) \mathrm{s}(\mathrm{III})$ & & \\
\hline$\delta(\mathrm{C}-\mathrm{H} 2)$ as & 1084.0 & $1088.5 / 1082.2$ \\
\hline$\delta(\mathrm{C}-\mathrm{H} 3)$ as & 1027.3 & $1030.8 / 1028.5$ \\
\hline$\delta(\mathrm{C}-\mathrm{H} 2) \mathrm{s}$ & 1017.7 & 1022.2 \\
\hline$\nu$ (ring 1$)$ as & 938.3 & $934.4 / 940.3$ \\
\hline$\delta(\operatorname{ring} 1) \mathrm{s}$ & 912.5 & 915.8 \\
\hline$\gamma(\mathrm{C}-\mathrm{H} 3)$ as $/ \gamma(\mathrm{C}-\mathrm{H} 3) \mathrm{s}$ & N.o. & 899.3 \\
\hline$\delta($ ring 2$)$ as & 885.4 & $884.7 / 881.1$ \\
\hline$\gamma(\mathrm{C}-\mathrm{H} 2) \mathrm{s}$ & 853.5 & 858.5 \\
\hline & N.o. & 845.8 \\
\hline$\gamma(\mathrm{C}=\mathrm{O})$ as & 815.8 & $819.8 / 814.6$ \\
\hline$\gamma(\mathrm{C}-\mathrm{H} 1) \mathrm{s}$ & 780.8 & $786.0 / 782.5 / 775.1$ \\
\hline$\gamma(\mathrm{C}-\mathrm{H} 1) \mathrm{s}$ & 765.3 & $770.8 / 768.5$ \\
\hline$\delta($ ring 1$)$ as & 765.3 & $759.9 / 753.8$ \\
\hline$\nu(\mathrm{C}-\mathrm{C})$ & 742.5 & 718.9 \\
\hline$\tau($ ring 2$) \mathrm{s}$ & N.o. & 629.8 \\
\hline$\tau($ ring 2$)$ as & 615.2 & $616.3 / 612.3$ \\
\hline$\tau($ ring 1$) \mathrm{s}$ & 591.4 & $590.6 / 587.0$ \\
\hline$\omega$ (ring) as & 510.3 & 511.0 \\
\hline$\gamma(\mathrm{C}=\mathrm{O}) \mathrm{s}$ & 470.0 & 481.9 \\
\hline
\end{tabular}

${ }^{a}$ Wavenumbers in $\mathrm{cm}^{-1} ; \nu$, bond stretching; $\delta$, bending; $\gamma$, rocking; $\omega$, wagging; $\tau$, torsion; s, symmetric; as, asymmetric; N.o., not observed. See Tables S1 to S5† for meaning of "approximate description". ${ }^{b}$ Except for where stated, all bands are due to each of the three conformers. ${ }^{c}$ In the crystal only form $\mathbf{I}$ is present. ${ }^{21}{ }^{d}$ These bands are due only to the less stable forms, II and III (see text).

\section{Infrared spectroscopy: $\alpha$-furil in $\mathbf{C C l}_{4}$ diluted solution at high temperature}

$\alpha$-Furil is weakly soluble in $\mathrm{CCl}_{4}$. Diluted $\left(<10^{-3} \mathrm{M}\right)$ solutions of the compound in $\mathrm{CCl}_{4}$ were prepared and changes in the IR spectrum with temperature were observed in the accessible temperature range $(298-353 \mathrm{~K})$. The relative populations of the conformers of $\alpha$-furil as a function of temperature were monitored in the spectral region corresponding to the $\nu$ (ring 4) vibration bands, $1400-1350 \mathrm{~cm}^{-1}$. This spectral region was chosen because of the absence of bands due to solvent absorptions and absence of significant overlap of bands due to the conformers of the solute, and is shown in

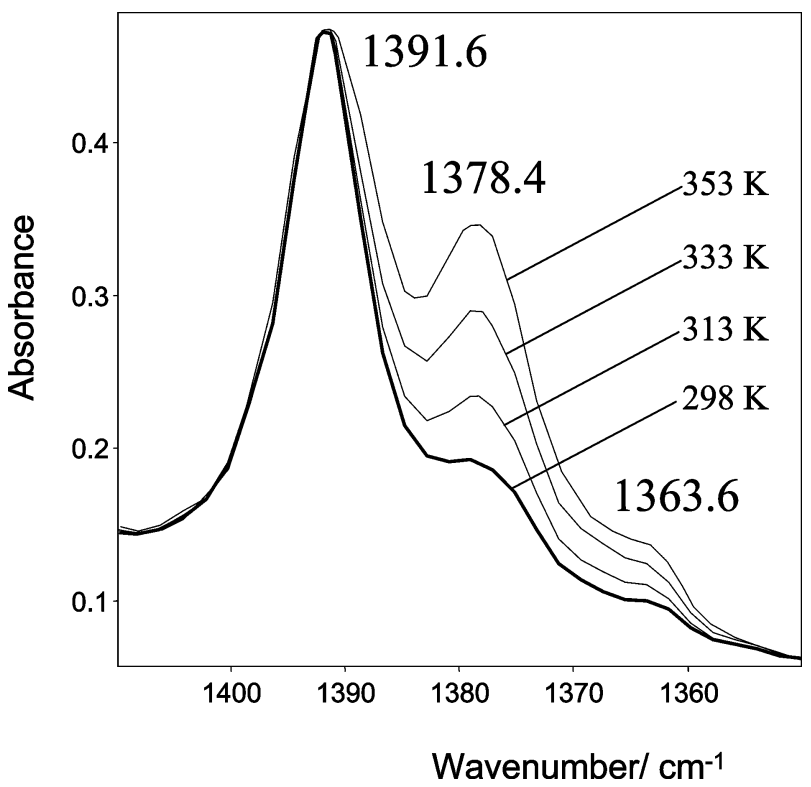

Fig. 10 Temperature variation of the $\nu$ (ring 4 ) band profile of the IR spectrum of $\alpha$-furil in $\mathrm{CCl}_{4}$ diluted solution $\left(<10^{-3} \mathrm{M}\right)$. Bands were normalized by the band at $1391.6 \mathrm{~cm}^{-1}$, due to conformer $\mathbf{I}$.

Fig. 10. There are three bands in this spectral range, at 1391.6, 1378.4 and $1363.6 \mathrm{~cm}^{-1}$. The highest frequency band reduces in intensity upon increasing the temperature and can be unequivocally ascribed to the most stable conformer, I, which is also predicted by the calculations to absorb at higher frequency, when compared with the remaining forms (see Table 3). The lowest frequency band increases only slightly in intensity with temperature and is most probably due to a combination tone $[\delta($ ring 1$)$ as $+\tau($ ring 1$)$ or $\gamma(\mathrm{C}-\mathrm{H} 1)+$ $\tau$ (ring 1)], whose fundamentals appear in the $760 \mathrm{~cm}^{-1}[\delta$ (ring $1)$ as and $\gamma(\mathrm{C}-\mathrm{H} \mathrm{1})]$ and $590 \mathrm{~cm}^{-1}[\tau($ ring 1$)]$ spectral regions, respectively. In turn, the mid-frequency band $\left(1378.4 \mathrm{~cm}^{-1}\right)$ considerably increases in intensity with temperature and can be assigned to the highest energy conformers, II and III. The assignment of this band to these conformers is supported by the calculations, which predicted the frequencies of the $\nu$ (ring 4) modes in these forms to be lower than that of the most stable form. A van't Hoff plot expressing the dependence of the relative intensities of the bands at 1391.6 and $1378.4 \mathrm{~cm}^{-1}$ with reciprocal temperature leads to an estimation of an "average" enthalpy difference between the higher energy forms and the most stable conformer of $7.2 \mathrm{~kJ} \mathrm{~mol}^{-1}$, which compares favourably with the predicted relative energies for conformers II and III of $\alpha$-furil (compared to conformer I) in the vacuum: 5.85 and $6.22 \mathrm{~kJ} \mathrm{~mol}^{-1}$, respectively (see Fig. 1).

\section{Conclusion}

$\alpha$-Furil was, for the first time, isolated in low temperature noble gas (argon; xenon) matrices and its molecular structure and vibrational signature probed by FTIR spectroscopy, supported by DFT(B3LYP)/6-311+ +G(d,p) calculations. The complete assignment of the spectra $\left(3500-400 \mathrm{~cm}^{-1}\right.$ range) was undertaken, revealing the presence in the matrices 
of three different conformers, all of them exhibiting skewed conformations around the intercarbonyl bond with the two $\mathrm{C}_{4} \mathrm{H}_{3} \mathrm{O}-\mathrm{C}(=\mathrm{O})$ fragments nearly planar. According to the theoretical calculations, the three conformers differ in the orientation of the furan rings relative to the carbonyl groups, which in the most stable conformer, $\mathbf{I}\left(C_{2}\right.$ symmetry), form a $\mathrm{O}=\mathrm{C}-\mathrm{C}=\mathrm{O}$ dihedral angle equal to $153.1^{\circ}$. In this conformer, the furan rings are oriented in such a way that one of their $\beta$ hydrogen atoms approaches the oxygen atom of the most distant carbonyl group, forming two $\mathrm{H}-\mathrm{C}=\mathrm{C}-\mathrm{C}-\mathrm{C}=\mathrm{O}$ sixmembered rings. The second most stable conformer, II $\left(C_{1}\right.$ symmetry), has an $\mathrm{O}=\mathrm{C}-\mathrm{C}=\mathrm{O}$ intercarbonyl dihedral angle equal to $126.9^{\circ}$ and one furan ring rotated by $c a .180^{\circ}$, resulting in an energetically less favourable $\mathrm{H}-\mathrm{C}=\mathrm{C}-\mathrm{C}=\mathrm{O}$ five-membered ring. Finally, the third conformer, III ( $C_{2}$ symmetry), is characterized by an $\mathrm{O}=\mathrm{C}-\mathrm{C}=\mathrm{O}$ dihedral angle equal to $106.2^{\circ}$ and has both furan rings rotated by $c a .180^{\circ}$ relative to the geometry exhibited by the most stable conformer. The theoretical calculations predicted the two higher energy forms being 5.85 and $6.22 \mathrm{~kJ} \mathrm{~mol}^{-1}$ higher in energy than the most stable form, respectively, and energy barriers for conformational interconversion higher than $40 \mathrm{~kJ} \mathrm{~mol}^{-1}$. The latter are high enough to prevent the conformational isomerization of the matrix isolated compound, which indeed was not observed experimentally even when the temperature of the matrix (xenon) was increased up to $80 \mathrm{~K}$. Evidence for different conformers of $\alpha$ furil were also found in the spectra of the compound in $\mathrm{CCl}_{4}$ diluted solutions and low temperature neat amorphous phase. On the other hand, in agreement with the available X-ray data, ${ }^{21}$ the IR spectra obtained for the neat low temperature crystalline state reveals that, in this phase, $\alpha$-furil exists uniquely in its most stable conformational state, $\mathbf{I}$.

\section{Acknowledgements}

This work was funded by Fundação para a Ciência e a Tecnologia (FCT), Portugal (POCTI/QUI/59019/2004 and POCTI/QUI/58937/2004), FEDER, CONICET and Agencia Nacional de Promoción Científica y Tecnológica (PICT 13080). We would also like to thank GRICES/SECyT for the award of the Collaborative Research Grant $00812 / / \mathrm{PO} /$ PA04-EIX/018). AGZ also thanks FCT for the grant SFRH/ BPD $/ 11499 / 2002$.

\section{References}

1 M. Pawlikowski, M. Zgierski and G. Orlandi, Chem. Phys. Lett., 1984, 105, 612.

2 S. Bera, R. Mukherjee and M. Choudhury, J. Chem. Phys., 1969, 51, 754 .

3 D. Morantz and A. Wright, J. Chem. Phys., 1971, 54, 692.

4 S. Bera, R. Mukherjee, D. Mukherjee and M. Choudhury, J. Chem. Phys., 1971, 55, 5826.

5 J. Arnett and S. McGlynn, J. Phys. Chem., 1975, 79, 626.

6 J. Arnett, G. Newkome, W. Mattice and S. McGlynn, J. Am. Chem. Soc., 1974, 96, 4385.

7 A. Gómez-Zavaglia and R. Fausto, J. Mol. Struct., 2003, 661-662, 195.

8 S. Lopes, A. Gómez-Zavaglia, L. Lapinski, N. Chattopadhayay and R. Fausto, J. Phys. Chem. A, 2004, 108, 8256.

9 A. Sing, D. Palit and J. Mittal, Chem. Phys. Lett., 2002, 360, 443.
10 M. Mizuno, K. Iwata and H. Takahashi, J. Mol. Struct., 2003, 661-662, 3 .

11 K. Das and D. Majumdar, J. Mol. Struct. (THEOCHEM), 1993 , 288, 55.

12 S. Lopes, A. Gómez-Zavaglia, L. Lapinski and R. Fausto, J. Phys. Chem. A, 2005, 109, 5560.

13 Q. Shen and K. Hagen, J. Phys. Chem., 1993, 97, 985.

14 T. Evans and P. Leermakers, J. Am. Chem. Soc., 1967, 89, 4380.

15 N. Leonard and P. Mader, J. Am. Chem. Soc., 1950, 72, 5388.

16 N. Leonard, T. Rapala, H. Herzog and E. Blout, J. Am. Chem. Soc., 1949, 71, 2997.

17 N. Leonard and E. Blout, J. Am. Chem. Soc., 1950, 72, 484.

18 A. K. Singh and D. K. Palit, Chem. Phys. Lett., 2002, 357, 173.

19 P. Migchels, G. Maes, T. Z. Huyskens and M. Rospeak, J. Mol. Struct., 1989, 193, 223.

20 Q. Shen and K. Hagen, J. Phys. Chem., 1987, 91, 1357.

21 S. C. Biswas, S. Ray and A. Podder, Chem. Phys. Lett., 1987, 134, 541.

22 Nippon Electric Company Ltd., Japan, Patent JP58,203,413, Chem. Abstr., 1984, 101, 219903.

23 T. T. J. Yu, (Energy Conversion Devices Inc.) Eur. Pat. Appli. EP 98018, Chem. Abstr., 1984, 100, 129945z.

24 G. D. Varamasov, I. A. Bekbulatov, Sh. K. Madaliev and Y. M. Mamatov, USSR Patent SU 758753, Chem. Abstr., 1984, 101, $111964 \mathrm{r}$.

25 I. Reva, S. Stepanian, L. Adamowicz and R. Fausto, J. Phys. Chem. A, 2001, 105, 4773.

26 M. Frisch, G. Trucks, H. Schlegel, G. Scuseria, M. Robb, J. Cheeseman, V. Zakrzewski, J. Montgomery, R. Stratmann, K. Burant, S. Dapprich, J. Millam, A. Daniels, K. Kudin, M. Strain, O. Farkas, J. Tomasi, V. Barone, M. Cossi, R. Cammi, B. Mennucci, C. Pomelli, C. Adamo, S. Clifford, J. Ochterski, G. Petersson, P. Ayala, Q. Cui, K. Morokuma, D. Malick, A. Rabuck, K. Raghavachari, J. Foresman, J. Cioslowski, J. Ortiz, A. Baboul, B. Stefanov, G. Liu, A. Liashenko, P. Piskorz, I. Komaromi, R. Gomperts, R. Martin, D. Fox, T. Keith, M. AlLaham, C. Peng, A. Nanayakkara, M. Challacombe, P. Gill, B. Johnson, W. Chen, M. Wong, J. Andres, C. Gonzalez, M. HeadGordon, S. Replogle and J. A. Pople, Gaussian 98 (Revision A.9), Gaussian Inc., Pittsburgh, PA, 1998.

27 A. D. Becke, Phys. Rev. A, 1988, 38, 3098.

28 C. T. Lee, W. T. Yang and R. G. Parr, Phys. Rev. B, 1988, 37, 785.

29 P. Csaszar and P. Pulay, J. Mol. Struct. (THEOCHEM), 1984, 114, 31 .

30 J. H. Schachtschneider, Technical Report, Shell Development Co., Emeryville, CA, 1969.

31 S. C. Biswas and R. K. Sen, Z. Kristallogr., 1985, 171, 235.

32 S. C. Biswas and R. K. Sen, Chem. Phys. Lett., 1983, 94, 415.

33 C. Condeiu, I. G. Dinulescu, G. Marton and F. Badea, Rev. Roum. Chim., 1994, 39, 733.

34 M. J. S. Dewar, A. J. Harget, N. Trinajstic and S. D. Worley, Tetrahedron, 1970, 26, 4505.

35 R. C. Elderfield and T. N. Todd in Heterocyclic Compounds, ed. R. C. Elderfield, John Wiley and Sons, New York, 1950, vol. 1, ch. 4.

36 W. A. Noyes Jr, G. B. Porter and J. F. Jolley, Chem. Rev., 1956, 56, 49.

37 H. Simbürger, W. Kern, K. Hummel and C. Hagg, Polymer, 2000, 41, 7883.

38 W. Adam, F. Kita and R. S. Oestrich, J. Photochem. Photobiol., A, 1994, 80, 187.

39 W. G. McGimpsey and J. C. Scaiano, J. Am. Chem. Soc., 1987, 109, 2179.

40 W. A. Chupka and C. Liftshitz, J. Chem. Phys., 1968, 48, 1109.

41 D. F. McMillen and D. M. Golden, Annu. Rev. Phys. Chem., 1982, 33, 493.

42 H. Q. Zhao, Y. S. Cheung, C. L. Liao, C. X. Liao, C. Y. Ng and W. K. Li, J. Chem. Phys., 1997, 107, 7230.

43 K. J. Hole and M. F. R. Mulcahy, J. Phys. Chem., 1969, 73, 177.

44 I. D. Reva, S. G. Stepanian, L. Adamowicz and R. Fausto, Chem. Phys. Lett., 2003, 374, 631.

45 A. J. Barnes, J. Mol. Struct., 1984, 113, 161.

46 I. Reva, A. Simão and R. Fausto, Chem. Phys. Lett., 2005, 406, 126. 